\title{
Monetary Policy, Macroprudential Policy, and Banking Stability: Evidence from the Euro Area*
}

\author{
Angela Maddaloni ${ }^{\mathrm{a}}$ and José-Luis Peydrób \\ ${ }^{a}$ European Central Bank \\ ${ }^{\mathrm{b}}$ Universitat Pompeu Fabra and Barcelona GSE
}

We analyze the impact on lending standards of monetary policy rates and macroprudential policy before the 2008 crisis, and of monetary rates and long-term public liquidity during the crisis. Exploiting the euro-area institutional setting for monetary and prudential policy and using the Bank Lending Survey, we find robust evidence that low monetary policy interest rates soften lending conditions unrelated to borrowers' risk in the period prior to the crisis, and some suggestive evidence of excessive risk-taking due to low interest rates for mortgage loans. Moreover, the impact of low monetary policy rates on the softening of standards is reduced by more stringent prudential policy on either bank capital or loan-to-value ratio. After the start of the 2008 crisis, we find that low monetary rates soften lending conditions that were tightened because of bank capital and liquidity constraints, especially for business loans. Importantly, this softening effect is stronger for banks that borrow more long-term liquidity from the Eurosystem. Therefore, the results suggest that monetary policy rates and public provision of long-term liquidity complement each other in reducing a credit crunch for firms.

JEL Codes: E51, E52, E58, G01, G21, G28.

*We thank Rafael Repullo (the editor) and an anonymous referee for their comments and suggestions. We also thank Stijn Claessens, Pierre-Olivier Gourinchas, Ayhan Kose, Soledad Martínez-Peria, Steven Ongena, Egon Zakrajsek, and the conference participants of the 2011 IMF Annual Research Conference, the IJCB Spring 2012 Conference, and the ECB Workshop on "Analysing the Role of Credit in the Macroeconomy." The views presented in this paper are those of the authors and should not be attributed to the European Central Bank or the Eurosystem. Author e-mails: angela.maddaloni@ecb.europa.eu and jose.peydro@upf.edu. 


\section{Introduction}

Since the start of the severe banking crisis of 2008, the question of how monetary policy affects banking stability has been at the center of an intense academic and policy debate. Concerning the period before the crisis, a key question is whether low monetary policy rates have spurred risk-taking by banks. Nominal rates during the 2002-05 period were the lowest in the last decades, below Taylor-rule implied rates, and even real rates were negative in several countries. ${ }^{1}$

While some recent literature shows that keeping monetary policy rates too low can increase banks' appetite for credit and liquidity risk due to banks' moral hazard problems (Jiménez et al. 2012b), overall the theoretical literature on this topic is inconclusive. In particular, recent theoretical banking micro-based work suggests that changes in the monetary policy rate may affect credit risk-taking by financial institutions. Allen and Gale (2000, 2004, 2007) show that under expansive monetary policy, and in the presence of bank moral hazard, risk-shifting in lending may occur. ${ }^{2}$ Adrian and Shin (2010a) describe the risk-taking channel of monetary policy and show that expansive monetary policy increases lending and risktaking by banks when their Value at Risk (VaR) constraint is binding in capital. Acute agency problems in banks, combined with a reliance on short-term funding, may therefore lead low short-term interest rates - more than low long-term interest rates - to spur risk-taking (Diamond and Rajan 2006, 2012). On the other hand, there are also mechanisms that could work in the other direction. Higher interest rates may, in general, increase the risk-taking incentives of borrowers due to moral hazard (Stiglitz and Weiss 1981) or even reduce the banks' net worth or charter value enough to make a "gambling

\footnotetext{
${ }^{1}$ See Taylor (2007 and 2008), Blanchard (2008 and 2009), Calomiris (2008), Besley and Hennessy (2009), Diamond and Rajan (2009), Allen and Carletti (2010), Rajan (2010a, 2010b), and Allen and Rogoff (2011), among others. See also Reinhart and Rogoff (2009) for a history of financial crisis.

${ }^{2}$ See Allen and Rogoff (2011, pp. 23-25) for a summary of the Allen and Gale (2000, 2004, 2007) models. Low short-term interest rates make riskless assets less attractive and may result in a search for yield, especially by those financial institutions with short-term time horizons (Rajan 2005, Blanchard 2008, and Borio and Zhu 2008; see also Holmström and Tirole 2011 and the many references therein, Borio and Lowe 2002, Dell'Ariccia and Marquez 2006, Dell'Ariccia, Laeven, and Marquez 2011, and Valencia 2011).
} 
for resurrection" strategy attractive (Kane 1989). These countervailing effects make the impact of the short-term interest rate on credit risk-taking ultimately a critical, yet largely unaddressed, empirical question.

A related question is whether prudential policy, by limiting moral hazard frictions, may reduce the impact of low monetary rates on risk-taking. But once the risk in the balance sheets of banks realizes and the crisis period starts, a central issue is whether low monetary rates and public provision of long-term liquidity may induce the banking sector to increase credit supply for firms and households. ${ }^{3}$

In this paper we empirically analyze these issues in the euro area, exploiting some unique features of the Monetary Union. First of all, the euro area represents a unique institutional setting with a common monetary policy but differences in the business and credit cycle and in prudential supervision. Moreover, in the euro area, funding to the corporate sector largely comes from banks and, therefore, a crisis affecting the banking sector has dramatic consequences for the real economy through the reduced credit provision. Finally, we take advantage of a unique data set on lending conditions for the euro area (the Bank Lending Survey, BLS) - where we know whether and why loan conditions change for the pool of all borrowers, including the rejected applications.

First, before the 2008 crisis, we analyze whether monetary policy rates affect lending terms and conditions for business and household loans, over and above other factors identified as culprits of the last crisis - in particular, low long-term interest rates and current account deficits, among others. ${ }^{4}$ In particular, we focus on whether monetary policy rates affect changes in lending conditions that can be related to bank credit supply factors. These factors are bank capital and liquidity constraints - balance sheet factors - and competition pressures. They are not related to changes in the net worth and credit risk of borrowers, which can be considered credit

\footnotetext{
${ }^{3}$ See, e.g., Bernanke and Blinder (1992), Bernanke and Gertler (1995), Kashyap and Stein (2000), Adrian and Shin (2010a), Gertler and Kiyotaki (2010), and Jiménez et al. (2012a). See also Giavazzi and Giovannini (2010).

${ }^{4}$ Low long-term rates and current account deficits may proxy for global imbalances for capital inflows (a key determinant of liquidity). These factors may have been important for the crisis (see Besley and Hennessy 2009, Diamond and Rajan 2009, and Bernanke 2010).
} 
demand factors related to the fundamentals of firms and households. Therefore, since these lending terms and conditions are unrelated to borrower quality, they reflect changes in credit and liquidity risktaking by banks. ${ }^{5}$

We analyze whether more stringent prudential supervision and regulation for banks affect the impact of monetary policy on lending standards. We use two cross-country measures of prudential banking policy. The first is a measure originally developed by researchers at the World Bank on the stringency of bank capital supervision, i.e., how stringent capital requirements are applied to the banking sector in each country. The other measure, more related to macroprudential policy, is based on the restrictions to the loan-to-value (LTV) ratios for mortgage loans applied in different countries. ${ }^{6}$ Second, once the 2008 crisis starts, we run a similar analysis and investigate whether lower monetary policy rates soften lending conditions and, in particular, lending conditions due to bank capital and liquidity problems (supply factors). Moreover, we also include in the analysis the longterm liquidity provision of the European Central Bank (ECB) - the key (non-standard) monetary policy measure that has been implemented in the crisis. In this way we analyze whether the potential softening of lending conditions is stronger in banking systems where banks have limited access to private liquidity in the wholesale markets and, therefore, resort more to the public liquidity from the Eurosystem (credit enhancement operations carried out by the ECB through full-allotment fixed-rate long-term liquidity-providing operations).

The empirical analysis of these questions in the euro area is of particular interest for three main reasons: (i) the European economy and its banking sector were heavily affected by the financial crisis. Moreover, bank financing constitutes around 75-80 percent of corporate funding in the euro area, ${ }^{7}$ (ii) the unique data on

\footnotetext{
${ }^{5}$ Banks take higher risk in their lending activity by granting loans with higher default probability and loss given default (credit risk), but also by lengthening the loan maturity as in Diamond and Rajan (2012), i.e., liquidity risk-taking.

${ }^{6}$ See Barth, Caprio, and Levine (2006) for the measure of stringency of bank capital and International Monetary Fund (IMF) (2011) for the restrictions on LTV ratios.

${ }^{7}$ See Allen, Chui, and Maddaloni (2004) for a comparison of the financial systems of Europe, the United States, and Asia.
} 
lending conditions in the euro area (from the Bank Lending Survey), as explained above and in section 2, allow the identification of bank credit supply (not related to non-financial borrower demand/fundamentals), and (iii) the Monetary Union provides a unique setting for this kind of analysis. Monetary policy (nominal) rates in the euro area are identical across countries, but there are significant differences in terms of GDP growth and inflation. ${ }^{8}$ Moreover, banking supervision (and even somewhat regulation) is a responsibility of the national authorities, whereas the monetary policy is set by the Governing Council of the ECB. Furthermore, as we will discuss also later, through time fixed effects we can control for unobservable time-varying common variables shocks that affect the monetary policy decisions of the ECB and lending standards - as, for example, commodity and oil price shocks or expectations on euro-area future GDP growth and inflation. In this case, the identification of monetary policy is largely cross-sectional, which allows us to deal with the typical endogeneity problem of monetary policy to local economic conditions.

A major identification challenge faced by researchers wanting to analyze the credit channel of monetary policy is to disentangle changes in loan demand and in loan supply. ${ }^{9}$ It is very difficult to obtain data on the lending conditions applied to the pool of potential borrowers (including households and firms that were rejected) and to know whether, how, and especially why banks change their lending conditions. The detailed answers of the confidential and unique Bank Lending Survey (BLS) for the euro-area countries provide this information. ${ }^{10}$ Importantly, the BLS reports and quantifies the factors affecting banks' decisions concerning change in lending conditions, which is a key piece of information to analyze credit and liquidity risk by banks. These factors can be grouped in (i) factors related to the quality and risk of loan applicants: net worth, collateral, and credit risk of borrowing firms and households (therefore credit

\footnotetext{
${ }^{8}$ See, e.g., Camacho, Pérez-Quiros, and Saiz (2008) and Taylor (2008).

${ }^{9}$ See Bernanke and Gertler (1995) and Bernanke (2007) for the definitions of the (broad) credit channel of monetary policy, the non-financial borrower (firm and household) balance sheet channel, and the bank lending channel (or bank balance sheet channel).

${ }^{10}$ See the appendix for details about the survey and Maddaloni and Peydró (2011) for a discussion on the reliability of the information contained in it.
} 
demand factors) and (ii) factors related to bank balance sheet capacity (capital and liquidity constraints and access to market funding) and competition pressures. These factors are not related to borrowers' risk, and we interpret them as identifying bank risk-taking. This detailed information that is available in the BLS is therefore crucial to identify the impact of monetary policy on loan supply and risk-taking.

We find robust evidence that-prior to the start of the 2008 crisis - low (monetary policy) short-term interest rates soften lending conditions and terms, for both firms and households. ${ }^{11}$ Specifically, low short-term rates soften lending conditions due to changes in bank net worth, liquidity, and competition (supply factors). When we include other factors that have been mentioned as possible culprits of the crisis, we note that the impact of low short-term rates on lending standards is statistically and economically more significant than the effect of low long-term interest rates or current account deficits. In fact, we do not find robust evidence that low longterm rates and current account deficits correlate with soft lending standards. Finally, concerning regulatory policies, we find that the impact of low monetary policy rates on the softening of lending standards is reduced by more stringent prudential policy on either bank capital or LTV - i.e., we find a heterogeneous impact of monetary rates on lending standards depending on the stringency of prudential policy.

The evidence that we present points to a general increase in the risk taken by the banks through their lending decisions in an environment of low interest rates. It is important to point out that even this evidence would be enough to argue that the stability of the entire banking system has been hampered and therefore the likelihood of a crisis has increased. In other words, even if each single bank takes consciously more risk and correctly accounts for that, the accumulation of risk in the system would be greater with potential negative externalities to the financial sector and the real sectori.e., systemic risk increases. However, we take one further step in

\footnotetext{
${ }^{11}$ Maddaloni and Peydró (2011) also show these results. They analyze changes in lending conditions and terms, whereas the key innovation of this paper is to analyze changes in lending conditions not related to borrower risk (i.e., to study bank risk-taking and credit supply).
} 
the analysis and try to analyze the issue of "excessive" risk-taking from banks. Indeed, we find some suggestive evidence consistent with "excessive" risk-taking in mortgage loans when interest rates are low. We find that lending conditions are softened for borrowers that are considered riskier by the banks (as opposed to average borrowers). In this analysis we control for key factors such as the business cycle, the long-term rates, the aggregate bank capital and liquidity position, and, crucially, for the changes in borrower risk and quality. Controlling for long-term interest rates is particularly important in this case, as mortgage loans have long maturity and the lending standards should therefore be less affected by short-term rates.

After the start of the 2008 crisis, we find evidence that low (monetary policy) short-term interest rates soften lending conditions and terms that were tightened because of bank capital and liquidity constraints. Moreover, these effects are stronger for banks that borrow more long-term liquidity provided by the Eurosystem through its "credit enhancement" policies (i.e., the banks with weaker balance sheets that are therefore more rationed in the wholesale market). ${ }^{12}$ All these results are robust for business loans. Therefore, the results suggest that monetary policy rates and public provision of longterm liquidity complement each other in reducing a credit crunch for firms. ${ }^{13}$

We also find that banks entering the crisis with a better capital position can soften lending conditions more than banks with higher capital constraints. All this evidence is consistent with the action of the bank lending channel of monetary policy, both through changes in monetary rates and non-standard monetary policy measures (see Bernanke and Gertler 1995; Kashyap and Stein 2000; Adrian and Shin 2010a; Gertler and Kiyotaki 2010) - i.e., monetary policy has an effect on the supply of credit (over and above changes in borrowers' quality and risk).

We make three specific contributions to the literature: (i) Given the detailed data available in the euro-area BLS, we can analyze whether there is evidence of risk-taking by banks by focusing on changes in lending conditions and standards not related to borrower demand (firm or household) fundamentals (risk and quality), but

\footnotetext{
${ }^{12}$ See Trichet (2009).

${ }^{13}$ See Jiménez et al. (2012a) for the analysis and identification of credit crunch.
} 
due to changes in bank net worth and competition (capital, liquidity, and competition), i.e., supply factors. This represents a step forward in the analysis of risk-taking compared with Maddaloni and Peydró (2011), where we analyze changes only in the overall lending conditions. Overall lending conditions depend also on borrowers' quality and net worth (which are affected by "demand" factors). We control explicitly for changes in credit demand (as reported in the BLS) and we analyze the impact of low interest rates on specific lending conditions such as loan spread, volume, maturity, collateral, and LTV. To identify excessive risk-taking, we analyze loan conditions that banks apply to riskier borrowers, over and above improvements in borrowers' quality and risk, bank capital and liquidity, and long-term interest rates. Moreover, we analyze the impact on lending standards (risk-taking) of monetary policy rates compared with other key factors mentioned as culprits of the crisis (in particular, current account deficits and long-term interest rates). (ii) We use LTV restrictions for mortgage loans to analyze the impact on lending standards of the interaction between monetary policy and macroprudential policy. (iii) During the time of the crisis, we investigate the impact of monetary policy on lending conditions and standards by considering changes in short-term monetary rates in conjunction with non-standard monetary policy measures carried out by the ECB through the full-allotment fixed-rate long-term liquidity operations - we analyze whether changes in monetary policy carried out by variations in short-term rates and in public provision of longterm liquidity complement (or substitute for) each other in softening lending standards.

The rest of the paper proceeds as follows. Section 2 describes the data and the methodological setup. Section 3 discusses the results, and section 4 presents the conclusions.

\section{Data}

\subsection{Lending Standards}

The main data set used in the study are the answers from the Bank Lending Survey for the euro area (the BLS). National central banks request that banks (senior loan officers, such as the chairperson of the bank's credit committee) provide quarterly information on the 
lending conditions and terms they apply to customers and on the loan demand they receive, distinguishing between business, mortgage, and consumer loans. ${ }^{14}$ Credit supply is monitored by asking about changes in lending conditions, about the factors responsible for these changes, and about the specific terms applied to customers (i.e., whether, why, and how lending conditions are changed).

The euro-area results of the survey - a weighted average of the answers received by commercial banks in each euro-area countryare published every quarter on the ECB's web site. In a few countries, the aggregate answers of the domestic samples are published by the respective national central banks. However, the overall sample including all the answers at the country and bank level is confidential.

Data from the euro-area BLS are available since 2002:Q4. The main set of questions did not change since the start of the survey. While data are currently available for the seventeen countries comprising the euro area, we restrict the analysis to the twelve countries in the Monetary Union as of 2002:Q4, thus we work with a balanced panel. Over this period we consistently have data for Austria, Belgium, Finland, France, Germany, Greece, Ireland, Italy, Luxembourg, Netherlands, Portugal, and Spain. The sample of banks is representative of the banking sector in each country. ${ }^{15}$ This implies that the sample generally includes banks of different size, although at the onset of the survey some preference was given to the inclusion of large banks. ${ }^{16}$

In the first part of the paper, we examine the impact of monetary policy on lending conditions and standards (bank risk-taking as defined in the Introduction) before the start of the financial crisis; i.e., we stop the analysis in 2008:Q3, in correspondence with the bankruptcy of Lehman Brothers and the start of the implementation of non-standard measures by the central banks. In the second part we analyze the crisis period up to 2010:Q4, when the Eurosystem

\footnotetext{
${ }^{14}$ We report only the results of the analysis on business and mortgage loans. Consumer loans amount to around 10 percent of the total outstanding amount of bank loans in the euro area.

${ }^{15}$ When foreign banks are part of the sample, the lending standards refer to the credit policy applied in the domestic market.

${ }^{16}$ See Berg et al. (2005), Ciccarelli, Maddaloni, and Peydró (2010), and Maddaloni and Peydró (2011).
} 
implemented the non-standard measures of liquidity provision to the banking sector (full-allotment, fixed-rate, long-term liquidity).

We use the answers related to the changes in lending standards over the previous three months (see Berg at al. 2005 and the appendix for a detailed description of the BLS questions). The questions imply only qualitative answers, and no figures are required: banks indicate softening, tightening, or no change of standards. Following, for instance, Lown and Morgan (2006), we quantify the different answers on standards by using the net percentage of banks that have tightened their lending standards over the previous quarter, which is defined as follows: the difference between the percentage of banks reporting a tightening of lending standards and the percentage of banks reporting a softening of standards. Therefore, a positive figure indicates a net tightening of lending standards. We calculate this variable for both corporate and mortgage loans.

As explained earlier, in order to identify the impact of low rates on bank risk-taking, in most regressions we use the answers related to the bank balance sheet factors affecting the decision to change lending standards. These factors are, in particular, capital and liquidity constraints and difficulty in accessing market funding. Since these factors are not related directly to borrower's risk, we consider these answers from the BLS as a good proxy for the capacity of banks to extend credit - in other words, a measure of credit supply. We focus on the role played by low interest rates and by the central bank liquidity provision in relaxing bank balance sheet constraints and ultimately supporting bank lending to the non-financial sector by increasing credit supply. We also look at the effect on credit supply of different supervision standards for bank capital and different norms for LTV ratios applied to mortgage loans across countries.

To give some flavor of the cross-country dimension of the BLS data, figure 1 shows how lending standards have changed over time in the euro area, in Germany, and in Italy. The figure shows that there is heterogeneity across the euro-area countries, both for credit demand and loan conditions unrelated to borrowers' net worth and risk. Although factors related to borrower risk (general economic outlook and borrowers' specific risks, the lightest shaded areas in the charts) have played a major role in affecting lending conditions since the start of the crisis, factors related to bank balance sheet factors (the mid-range shaded areas) have been important as well 


\section{Figure 1. Lending Standards and Demand for Loans}
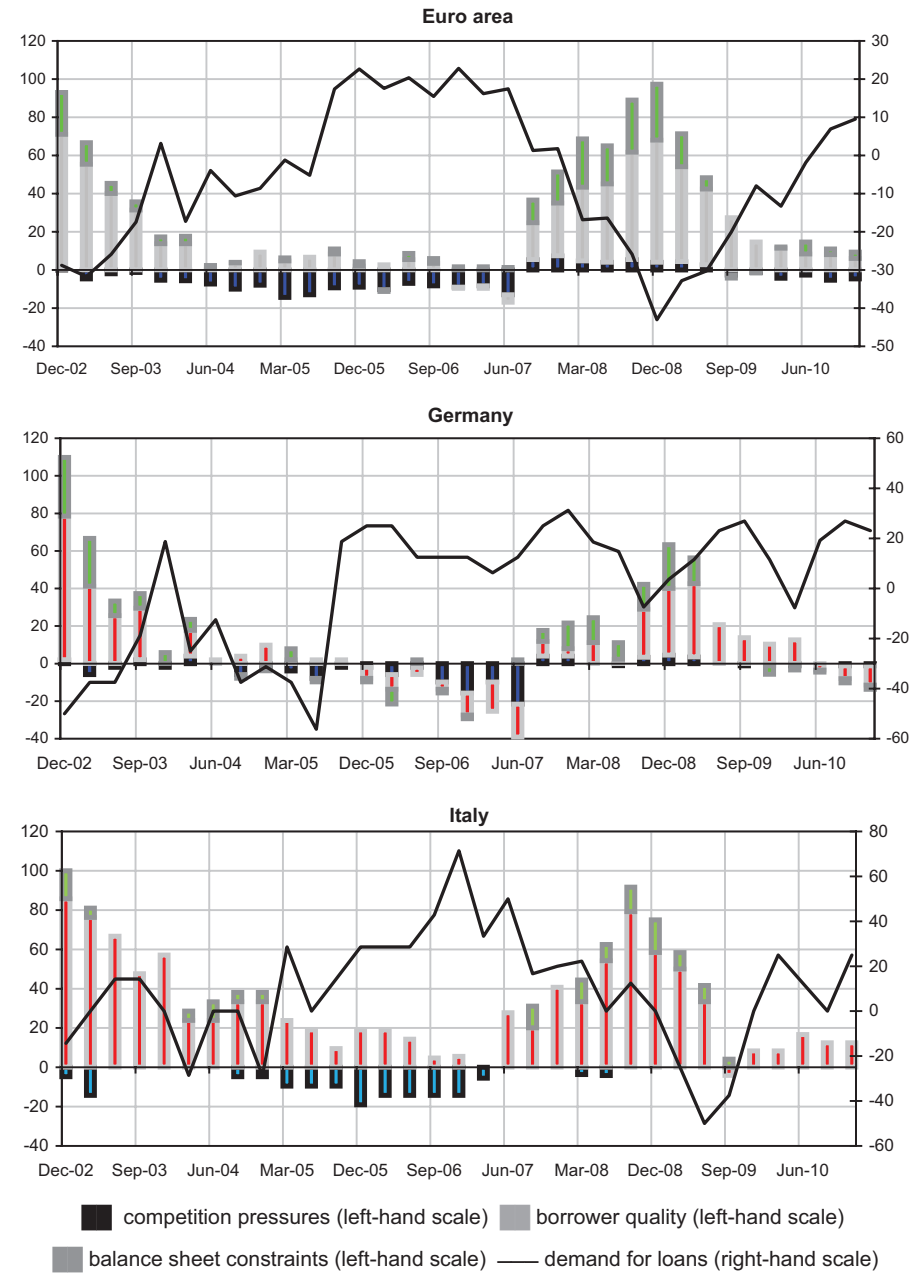

Sources: European Central Bank, Deutsche Bundesbank, and Banca d'Italia. Notes: This figure plots the lending standards and the demand for loans in the euro area, in Germany, and in Italy as reported in the Bank Lending Survey. The responses refer to business (non-financial corporations) loans. Competition pressures is the average of the responses to the questions referring to competition factors affecting the decision to change lending standards (bank, non-bank, and market financing competition). Balance sheet constraints is the average of the responses to the questions referring to balance sheet factors affecting the decision to change lending standards (capital position, liquidity position, and market financing conditions). Borrower quality is the average of the responses to the questions referring to borrower risk factors affecting the decision to change lending standards (economic outlook and borrower-specific risks). They are the answers to questions 2 and 4 of the BLS. 
and resurfaced in the last quarters of our sample due to the intensification of the sovereign crisis and the difficulties of banks to access funding. At the same time, during the boom years, lending conditions, especially due to bank balance sheet factors and competition, were softer. The charts also show changes in the demand for loans, highlighting the cross-country differences.

Since lending standards set by the banks may be influenced also by the loan demand received, we use the responses from the BLS related to the demand for loans as a control variable in the regressions.

Table 1A describes the summary statistics of overall lending conditions and lending conditions due to changes in bank balance sheet factors, before the crisis and during the crisis. In the appendix we report the main questions of the BLS and the mapping between these questions and the variables that we use in the analysis.

\subsection{Macroeconomic and Financial Variables}

The macro and financial variables included in the main analysis are short-term (monetary policy) rates, long-term (government bond) interest rates, current account balance (over GDP), GDP growth, inflation, supervision standards for bank capital, and restrictions on the maximum loan-to-value ratio applied to mortgage loans. We also collect data on total bank capital ratio and on bank liquidity (interbank ratio) from the balance sheets of the sample of banks of the euro-area countries included in Bankscope. ${ }^{17}$ In the analysis during the crisis we also use data on the liquidity provisions of the Eurosystem to euro-area banks, and we concentrate in particular on the long-term refinancing operations (from three-month to one-year maturity). Table 10 in the appendix details all the variables and the data sources.

Before the crisis, we make use of two different measures to identify monetary policy. First, we use the quarterly average of the EONIA rate, the overnight interest rate for unsecured interbank

\footnotetext{
${ }^{17}$ In Bankscope, the interbank ratio for a bank is defined as the funds lent to other banks divided by the funds borrowed from other banks. If this ratio is greater than 100, then the bank is a net lender of funds in the interbank market, and therefore it is more liquid.
} 
Vol. 9 No. 1

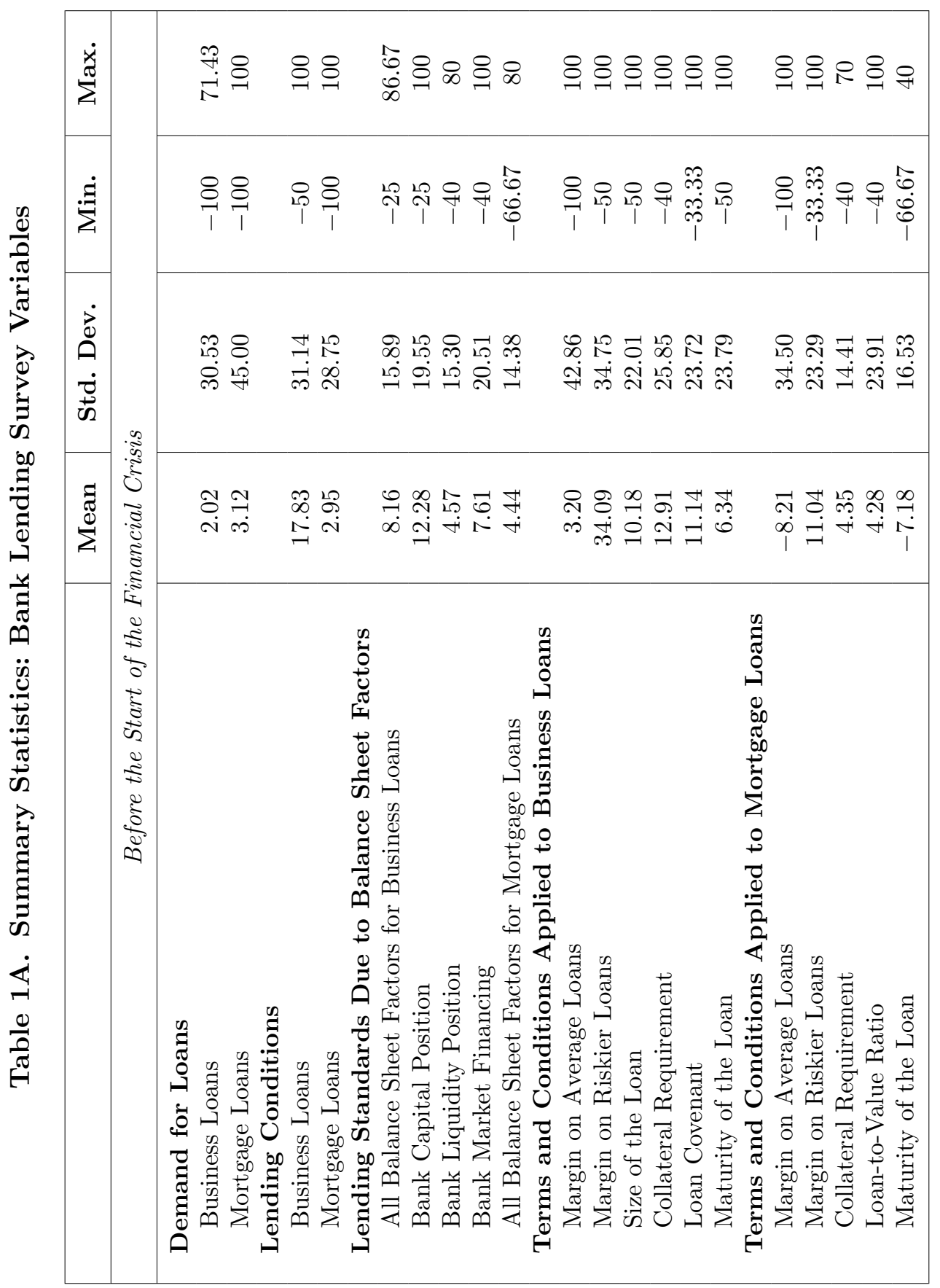




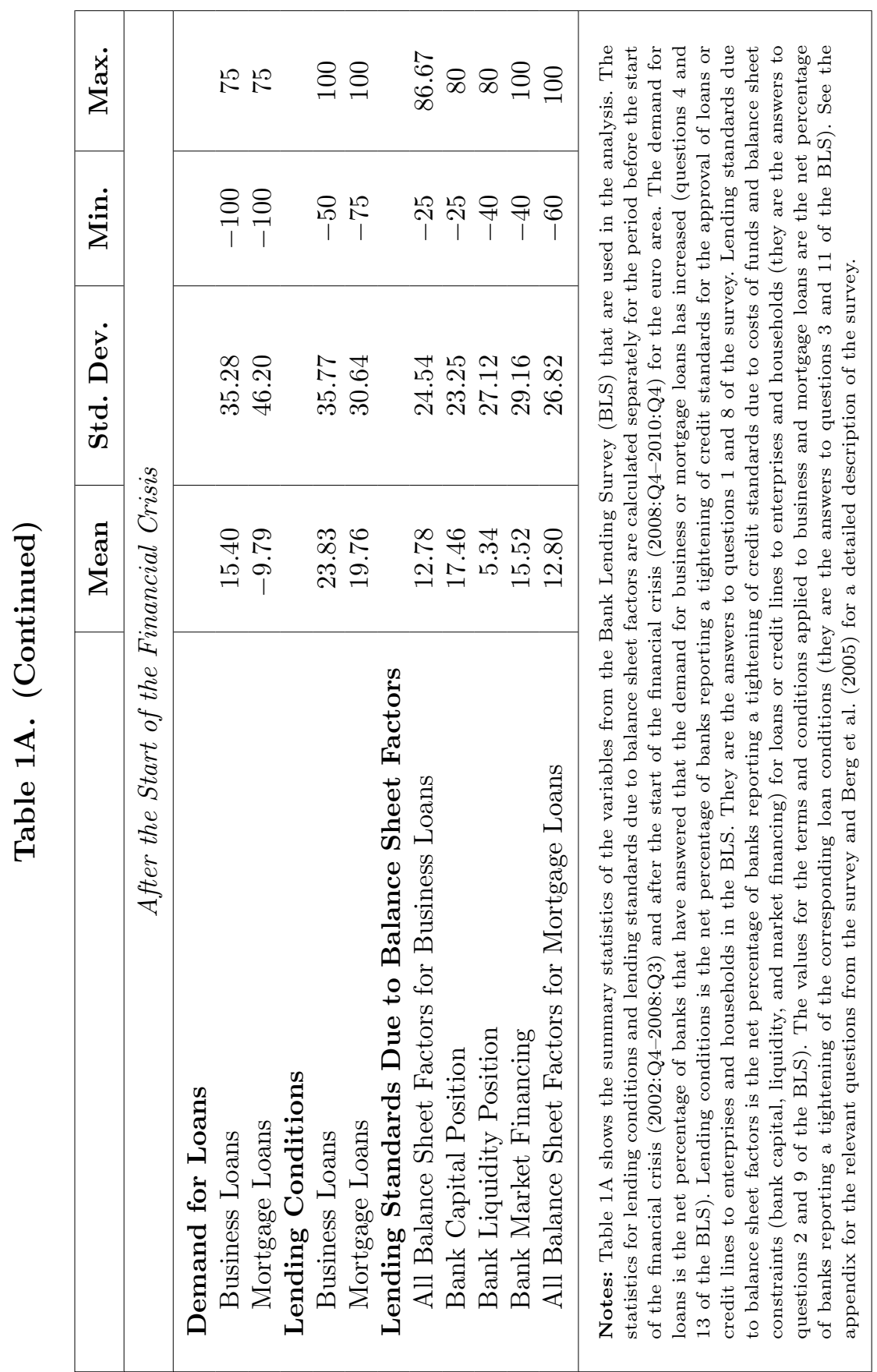


transactions in the euro area (as published by the ECB). ${ }^{18}$ To control for the endogeneity of monetary policy, we use cross-sectional variation of monetary conditions as measured by the Taylor-rule residuals obtained by regressing the overnight rates on GDP growth and inflation. ${ }^{19}$ We estimate the residuals for the euro area with panel least-squares (LS) regressions, imposing common coefficients for all twelve countries, given the common monetary policy. A positive residual indicates relatively high monetary policy rates (tight monetary conditions for certain countries), while negative residuals proxy for low rates (soft conditions). Figure 2 shows the changes of Taylor-rule residuals for the euro area and their volatility. There is a lot of variation of Taylor-rule residuals during our sample period and this variation is exactly what we want to exploit.

In the second part of the analysis, when we estimate the impact of low monetary rates during the crisis times, we also characterize monetary policy with an additional variable, the outstanding amount of long-term liquidity (with maturity between three months and one year) that the central banks provided to the banking sector of each euro-area country (scaled by GDP). Longer-term refinancing operations (where banks could go to the central banks of the Eurosystem and get liquidity in exchange of collateral for up to one year) and the full-allotment policy (no limit to the amount of liquidity provided in exchange for collateral) are the most important non-standard monetary policy measures implemented by the ECB. EONIA rates were affected by the overall effect of the fixed-rate full-allotment liquidity policy (implying that EONIA rates dropped at levels substantially

\footnotetext{
${ }^{18}$ In the United States, the overnight interest rate has been used as an indicator of the U.S. stance of monetary policy by Bernanke and Blinder (1992) and Christiano, Eichenbaum, and Evans (1996), among others. In the euro area, the Governing Council of the ECB set the values of the three key policy rates defining the corridor where the overnight money-market rate (EONIA) can fluctuate. Therefore, the overnight rate is also a sensible measure of the monetary policy stance in the euro area.

${ }^{19}$ See also Maddaloni and Peydró (2011). The purpose of this exercise is to exploit the cross-sectional variation of monetary policy conditions in the euro area reflecting the fact that monetary policy rates are identical for euro-area countries but GDP and inflation remain different. Therefore, we are interested mainly in identifying differences in monetary policy shocks across countries more than correctly identifying the size of monetary policy shock for each country, which would require the estimation of more precise Taylor rules possibly including other variables in addition to GDP and inflation.
} 


\section{Figure 2. Taylor-Rule Residuals in the Euro Area}

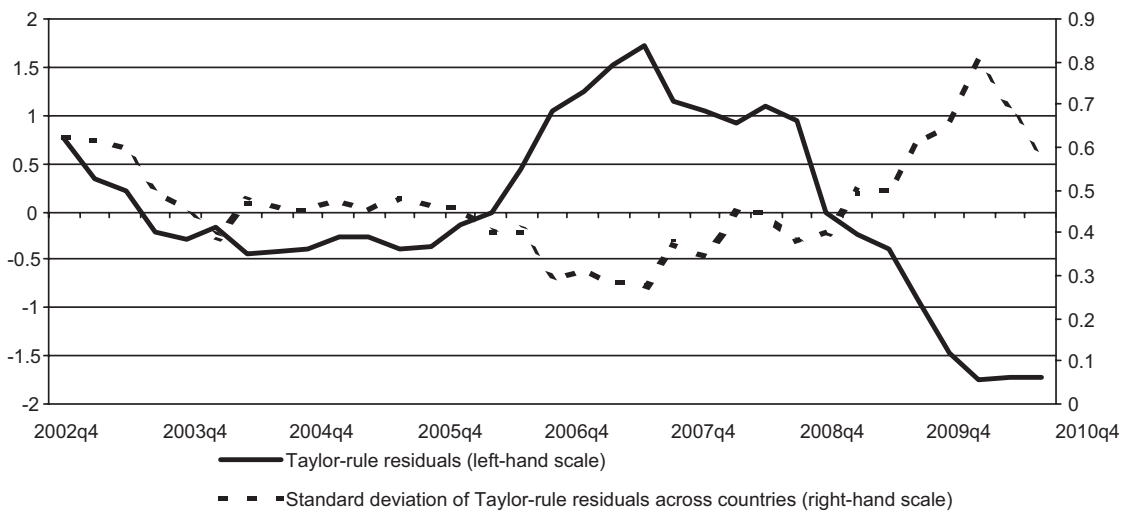

Notes: This figure shows the Taylor-rule residuals for the euro area and the crosscountry volatility of Taylor-rule residuals. Taylor-rule residuals are the residuals of the regression of EONIA rates on GDP growth and inflation. The residuals are estimated separately for each country in the euro area, and a weighted average is calculated using country GDP. The residuals are calculated for twelve euro-area countries (Austria, Belgium, Finland, France, Germany, Greece, Ireland, Italy, Luxembourg, the Netherlands, Portugal, and Spain).

lower than the MRO (policy) rate after the implementation of the full allotment). In addition, we include the cross-country heterogeneity over time in the banks' borrowing at the Eurosystem liquidity operations (with maturity higher than three months). We analyze how these measures have interacted with monetary conditions, as defined by Taylor-rule residuals.

Global imbalances have often been mentioned as significant factors contributing to the crisis. These global imbalances resulted in very low levels of interest rates over the maturity spectrum and in considerable current account deficits. Therefore, we include in the analysis the ten-year government bond interest rate and the current account balance (as percentage of GDP) for each euro-area country to take into account global imbalances.

The main macroeconomic controls are the annual real GDP growth rate and the inflation rate, defined as the quarterly average of monthly inflation rates expressed in annual terms. We also include in the model the interbank ratio and the total capital ratio to control for bank liquidity and capital position. These measures 
are the median values at the country level of the ratios on total bank capital and interbank ratio from the sample of banks reported in Bankscope.

It has been argued that regulatory arbitrage for bank capital has been key in precipitating the financial crisis (Acharya and Richardson 2009). To shed some light on this matter, we look at the impact of low interest rates on lending conditions, controlling for supervision standards. We use a bank capital stringency index as a measure of supervision standards for bank capital. Capital stringency is an index of regulatory oversight of bank capital which quantifies the supervisory approach to assessing and verifying the degree of bank capital at risk (Barth, Caprio, and Levine 2006, Laeven and Levine 2009).

A measure that it is often mentioned as a possible tool for macroprudential policy is the imposition of limits to the loan-to-value ratios applied to mortgage loans. This tool is particularly important since it is directed to the mortgage market, where the most significant imbalances accumulated before the current crisis. We include in the analysis a measure of the LTV ratio restrictions applied in different euro-area countries; we take this information from a recent IMF publication (IMF 2011).

Table 1B provides the summary statistics of all these variables. It is important to note that there is ample cross-country and over-time heterogeneity in Taylor-rule residuals, business cycle, and lending conditions (see also figure 1 for the variation over time in the euro area, Germany, and Italy of lending conditions).

In terms of methodology, we estimate a series of panel regressions of the form

$$
\mathrm{LS}_{i, t}=\alpha_{i}+\beta X_{i, t-1}+L S_{i, t-1}+\varepsilon_{i, t},
$$

where $L S_{i, t}$ are the measures of lending conditions from the BLS at time $t$ for country $i$ and the vector $X_{i, t}$ contains all the monetary policy, financial, and macro variables. All the explanatory variables are lagged by one quarter to control for endogeneity, and we also include the lagged dependent on the right-hand side to control for autocorrelation. We estimate the panel regressions first using 


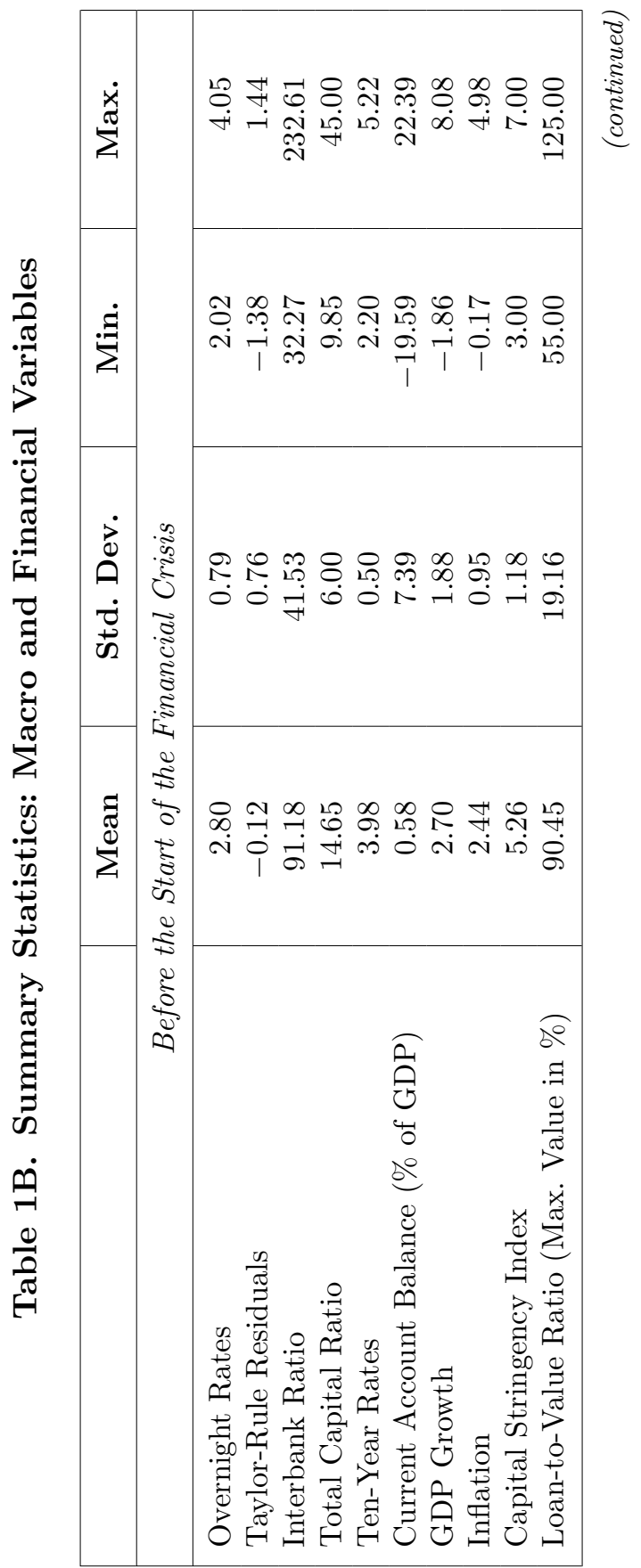




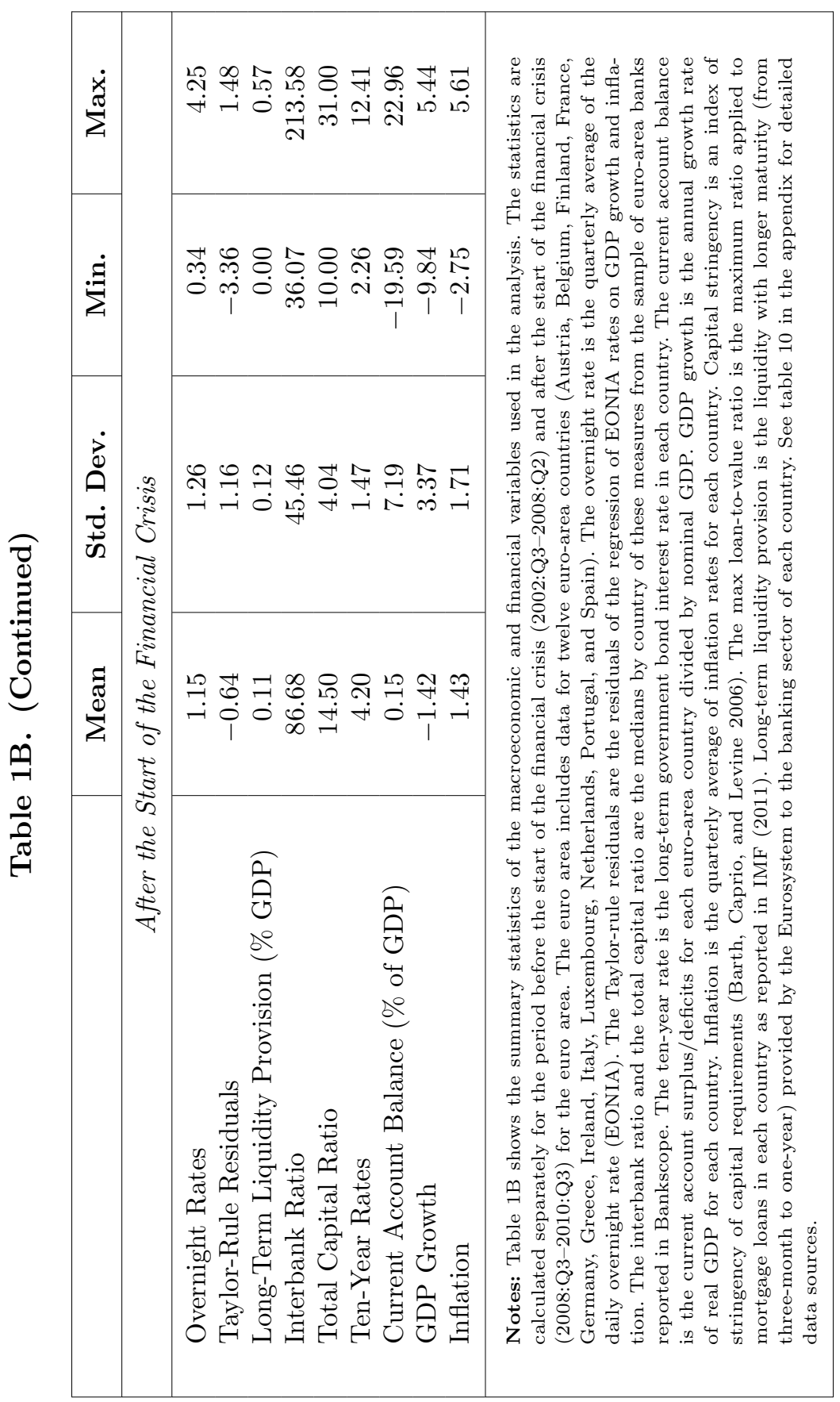


generalized least squares (GLS), which allows us to control for crosscountry correlation and heteroskedasticity. Since the coefficient of the lagged dependent variable is significant, GLS estimation may be biased when including fixed effects. Therefore, we resort in most of the regressions to the GMM estimator proposed by Arellano and Bond 1991 (see also Arellano 2003), which uses lags of the dependent variable as instruments. All estimations are carried out using robust standard errors. ${ }^{20}$

\section{Results}

We first analyze the lending conditions and standards until 2008:Q3, the date that we consider as the starting point of the crisis (tables 25 ). Next, we run a similar analysis during the crisis time (tables 6-8), until 2010:Q4. We also provide some robustness analysis in an appendix.

\subsection{Lending Conditions and Standards Before the Crisis}

The results are reported as follows. First, we analyze the impact of short-term interest rates on overall lending conditions without any controls (table 2). Then, we repeat similar regressions including all the control variables we discussed in the previous section and time and country fixed effects (table 3 ). Table 4 shows the results of regressions where the dependent variables are the specific terms and conditions for the loans. Finally, in table 5 we analyze the interaction of monetary policy and banking prudential policies on lending conditions and standards (LTV restrictions and bank capital stringency).

Table 2 shows that lower monetary policy rates, either measured by overnight rates or Taylor-rule residuals, imply a softening of

\footnotetext{
${ }^{20}$ The Nickel bias induced by the presence of the lagged dependent variable with the country fixed effects would converge to zero for a $\mathrm{T}$ sufficiently high (with the rule of thumb in the literature being more than twenty periods). In this case, estimation by GLS would be unbiased in our sample. Using GMM to run the regressions as shown in table 3 and successive tables yields broadly similar results. In the second part of the paper, when we run the analysis during crisis times, we have fewer than twenty periods; however, results are robust to not including lagged credit standards (unreported results available upon request).
} 


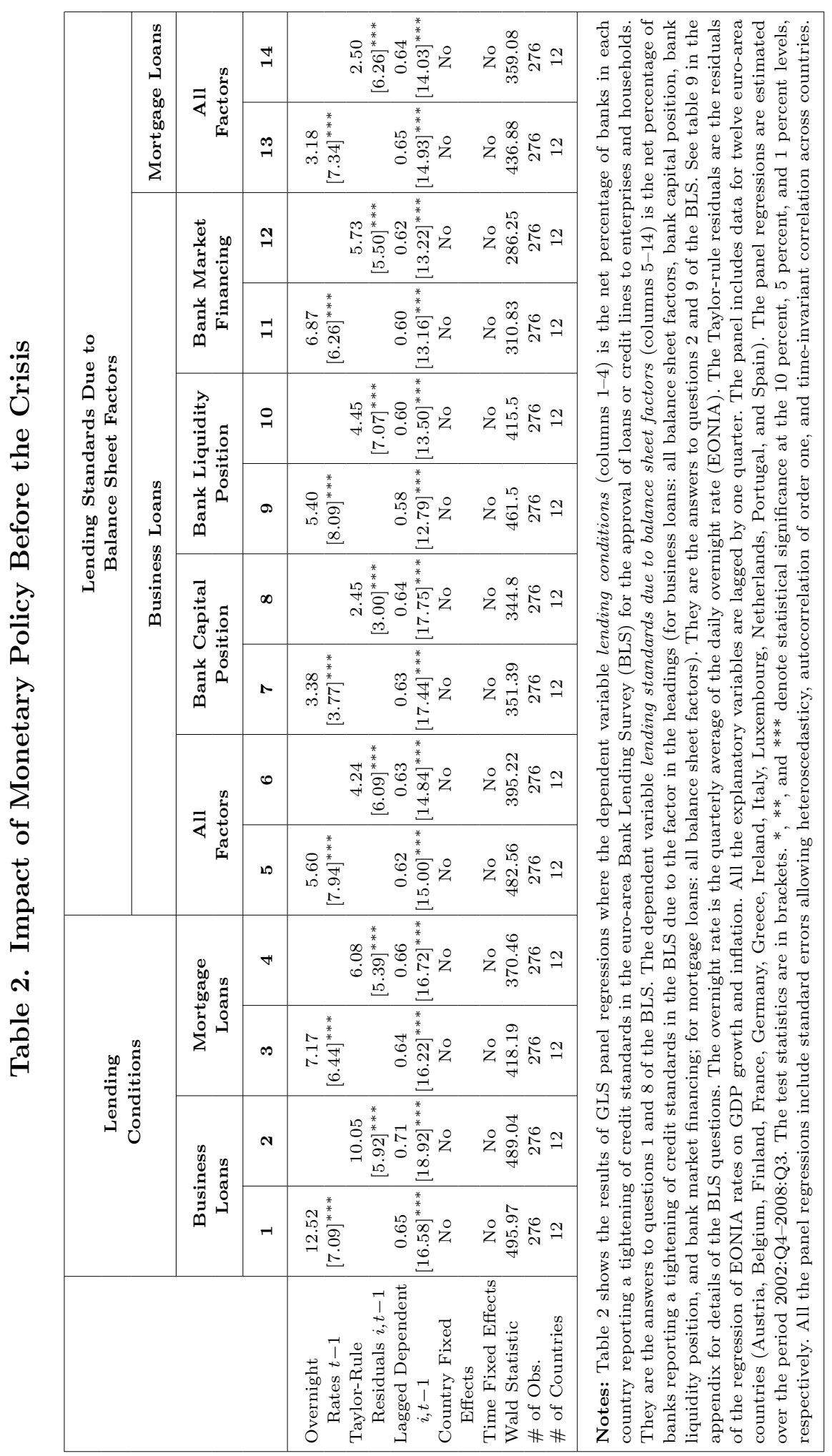


overall lending conditions (columns 1-4) and of lending conditions due to bank balance sheet constraints (columns $5-14$ ). The results are obtained with GLS panel estimation including the lagged lending standards as regressors to control for autocorrelation.

In the other tables (tables 3-5), we include all the controls, including country fixed effects. We also include time fixed effects to control for unobservable time-varying common shocks that affect lending standards and ECB monetary policy decisions - as, for example, commodity and oil price changes or expectations on euro-area future GDP growth and inflation. ${ }^{21}$ Since the coefficient in table 2 of the lag is positive and significant, the results of the GLS estimation can be biased, and therefore we use in the following regressions the GMM estimator, using lags of the dependent variable as instruments.

Table 3 shows that the results of table 2 are robust to the inclusion of key controls as country and time fixed effects, GDP growth, inflation, long-term interest rates, current account balance, credit demand changes, and aggregate bank capital and liquidity. The estimation confirms that lower monetary policy rates (measured by Taylor-rule residuals) are followed by softer lending conditions, measured by overall lending conditions and standards but also by lending standards related to bank balance sheet factors.

All in all, the analysis shows that monetary policy rates affect changes in lending conditions related to changes in bank net worth stemming from changes in bank capital and liquidity. The results indicate that monetary policy affects credit and liquidity risk-taking, since banks soften lending conditions even when holding constant borrower credit risk. Moreover, results are robust to the inclusion in the analysis of aggregate bank liquidity and capital ratios. This suggests that low short-term rates soften lending conditions over and above the current balance sheet position of banks, thus hinting to a mechanism implying a change in risk aversion (see Borio and Zhu 2008).

Current account balance is not highly correlated with lending conditions and, if anything, current account deficits are associated with tighter lending conditions (see column 3). The coefficients of

\footnotetext{
${ }^{21}$ All regressions in which we introduce controls include time fixed effects. Results of the same regressions without time fixed effects are available upon request.
} 
Vol. 9 No. 1

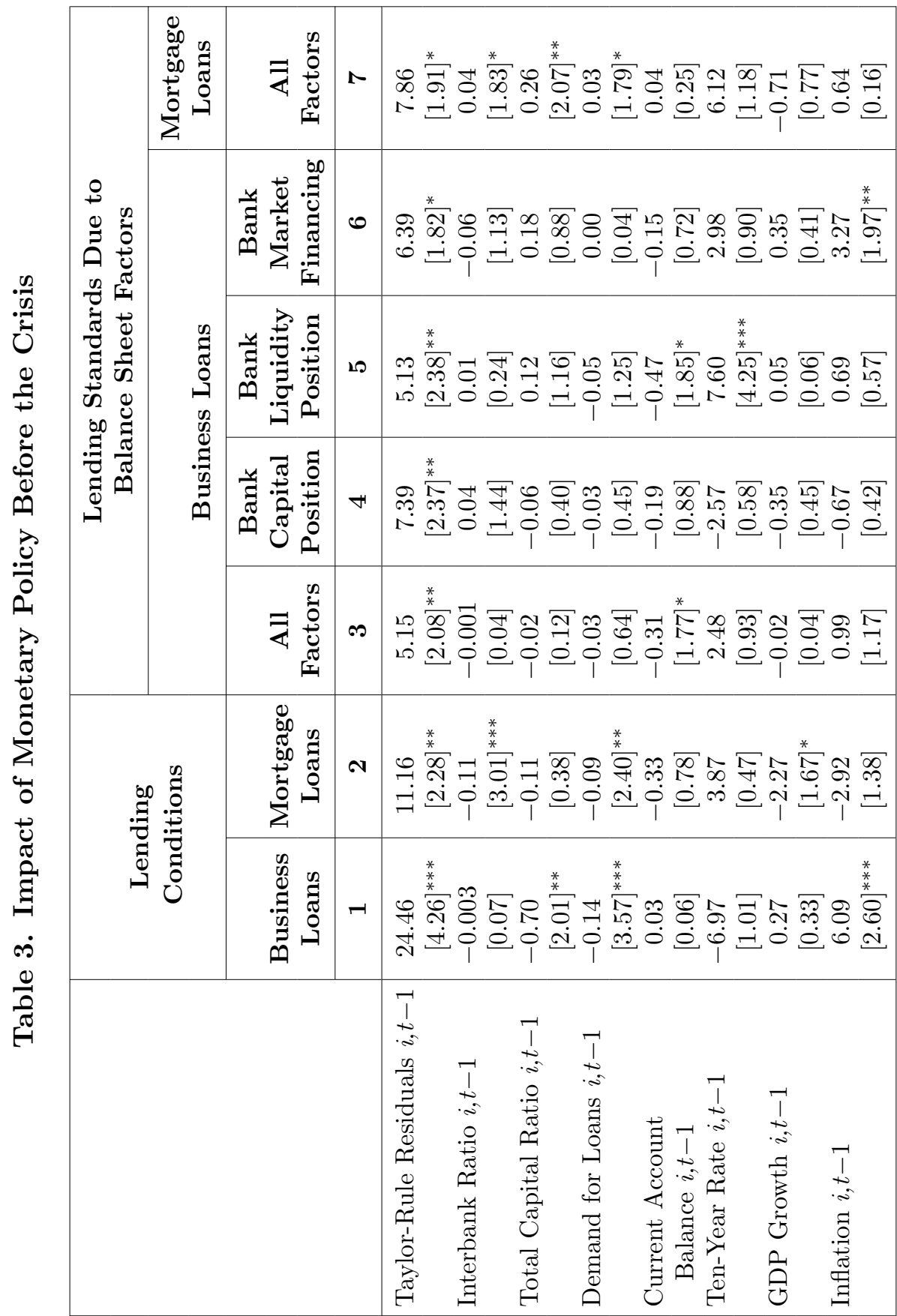




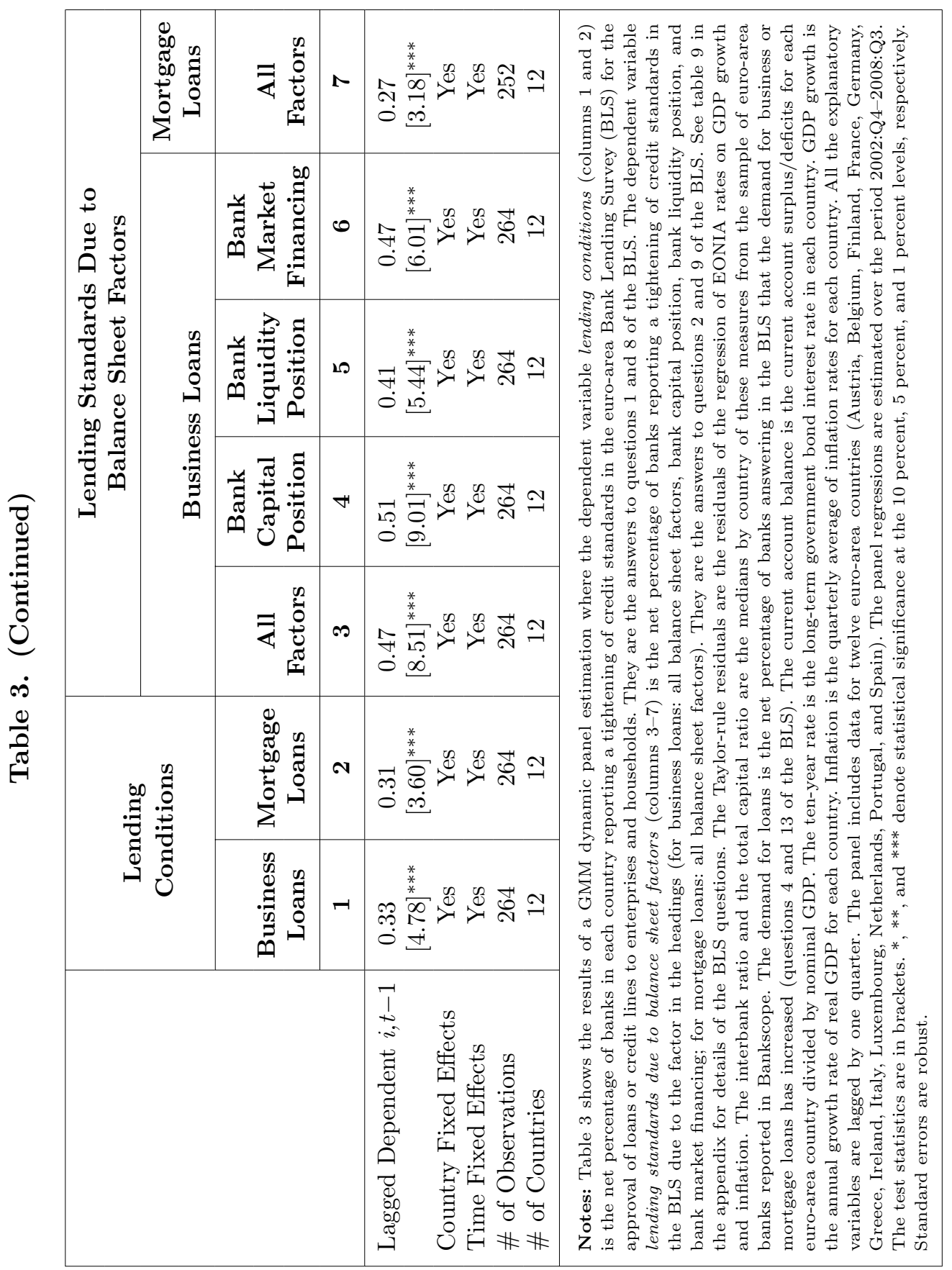


current account balance and long-term rates are generally not statistically significant, which suggests that the impact of low short-term rates on credit and liquidity risk-taking is statistically and economically more significant than the effect of low long-term interest rates or current account deficits.

The BLS provides a qualitative indication of changes in lending conditions; therefore, it is difficult to estimate the size of the impact produced by these changes. Nevertheless, looking at the information from the summary statistics of table 1 and the coefficients of table 3 of Taylor-rule residuals and of the key controls (like GDP), we can conclude that the impact of monetary policy is also economically significant in explaining lending conditions - as the coefficients of monetary rates, also taking into account the standard deviations, are higher in absolute terms than the coefficient of GDP, and GDP is important in explaining changes in lending standards, as emphasized in Ruckes (2004) and Dell'Ariccia and Marquez (2006), among others.

In table 4 we analyze the impact of monetary policy on the specific terms and conditions of loans. It is notable that low short-term rates have a significant softening impact on margins (lending rates) applied to both average and riskier loans, but also on loan volume, collateral, maturity, covenants, and LTV. These results suggest that banks take higher credit risk in granting new loans when monetary policy rates are lower (lower spreads to riskier marginal borrowers, covenants, and collateral). As they also lengthen the maturity of loans, at least for business loans, they also take higher liquidity risk.

In the last two columns of table 4, we take a step forward in the analysis and estimate two different regressions to investigate the notion of "excessive" risk-taking - of course with the caveat that identifying excessive risk is a very difficult empirical task. We regress the changes in loan margins applied to riskier loans on Taylor-rule residuals. We control for the changes in lending conditions due to variations in borrowers' net worth from the BLS (therefore holding constant borrowers' quality $)^{22}$ and for all the other controls. The

\footnotetext{
${ }^{22}$ Specifically, these are the lending standards tightened because of increased perception of risk: changes in general economic conditions, in industry/firm outlook, and in risk of collateral (for business loans) and changes in housing market prospects (for mortgage loans). See table 9 in the appendix, answers to questions 2 and 9 , factors $\mathrm{C}$.
} 


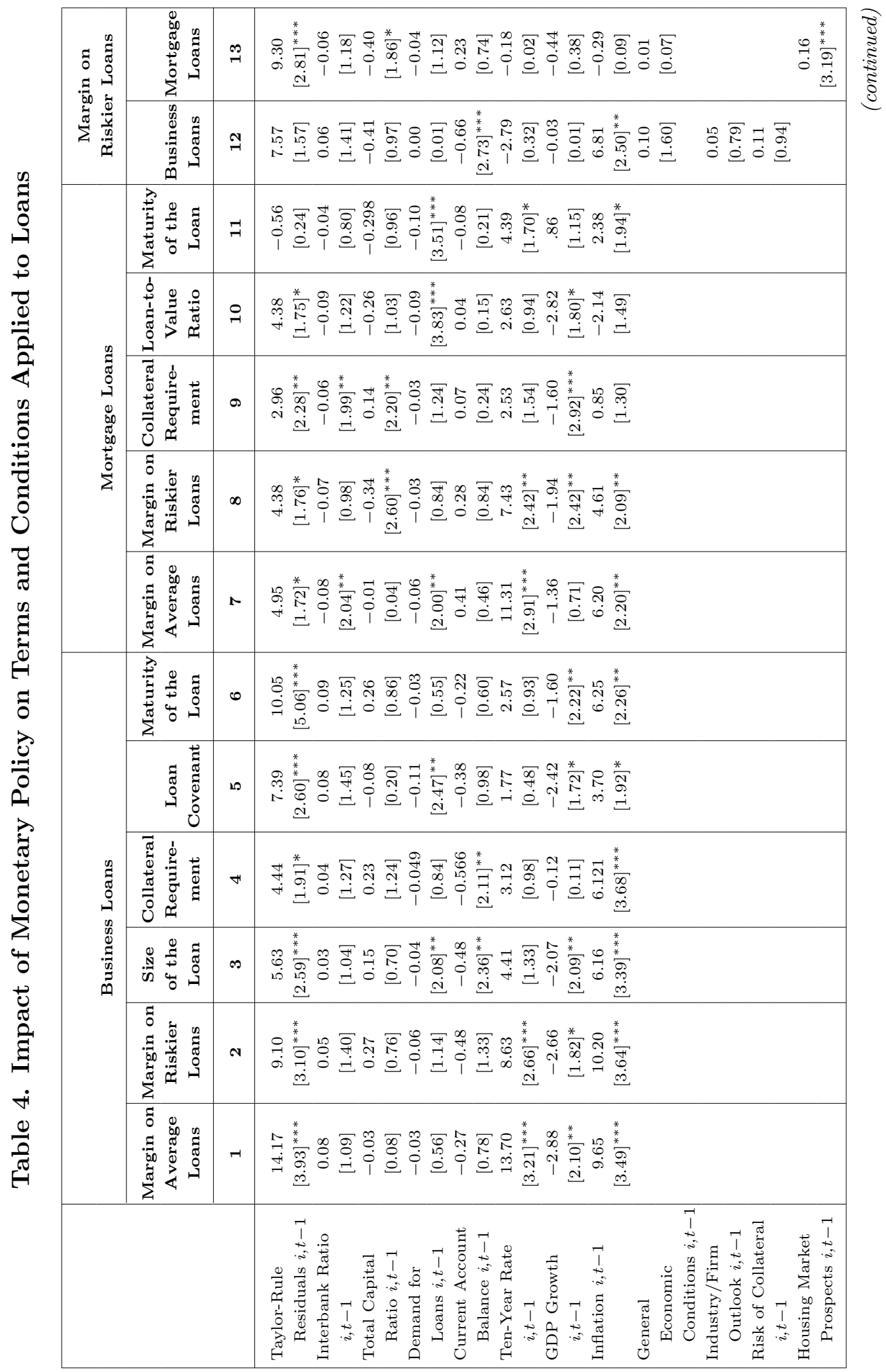




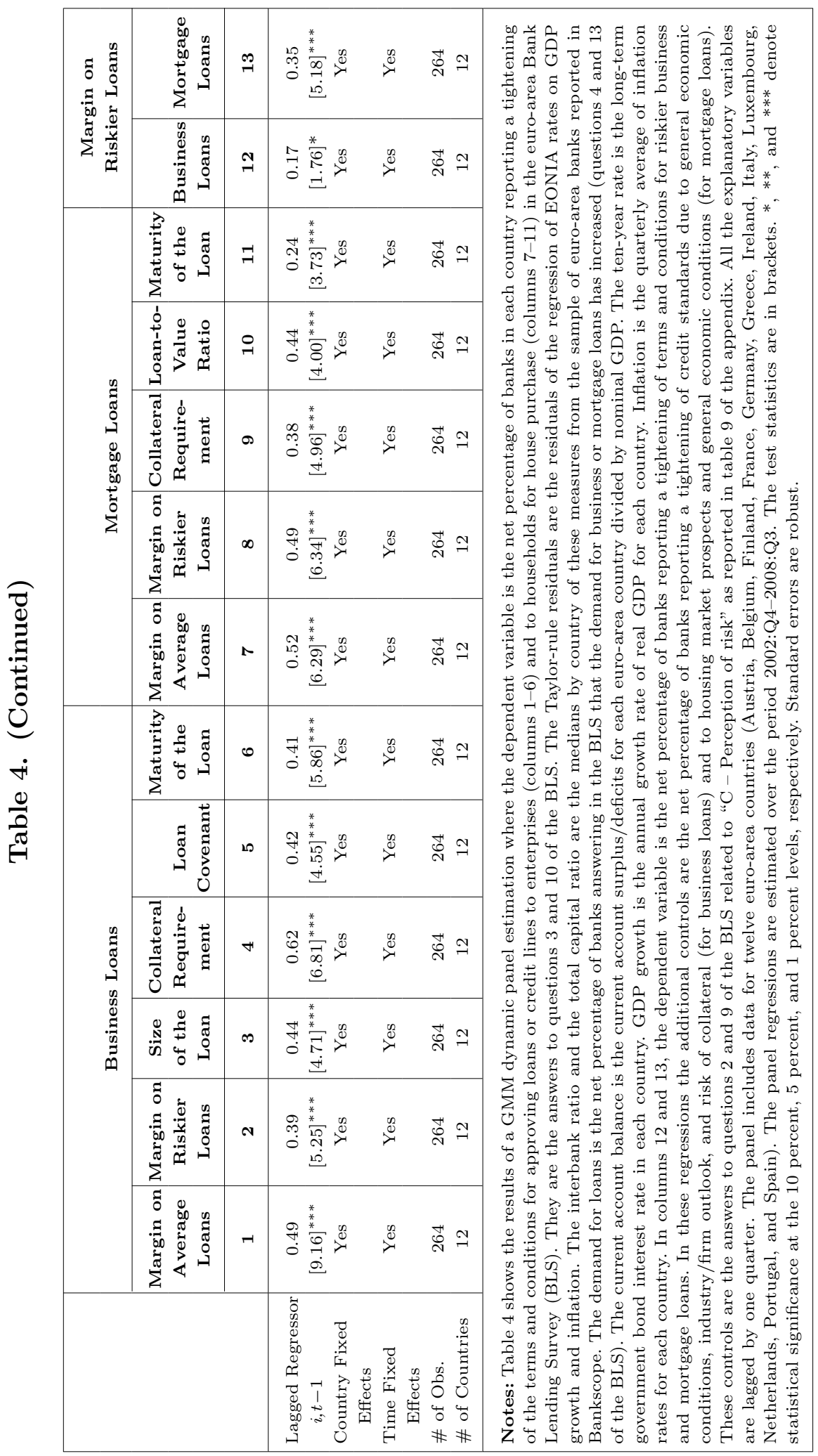


coefficient of Taylor-rule residuals for the regression using lending standards for mortgage loans remains significant. This result suggests that before the onset of the financial crisis, with lower monetary rates, banks softened margins on mortgage loans even for borrowers that they considered riskier, holding constant credit risk. ${ }^{23}$ This result is robust to the inclusion of the relevant interest rates (the long-term rates) and also the aggregate bank capital and liquidity (therefore controlling for the more classical bank lending channel). Results therefore suggest excessive risk-taking in bank lending when monetary policy rates are low.

Finally, in table 5 we analyze the interaction between monetary policy rates (Taylor-rule residuals) and banking prudential supervision/regulation measures. We use two key policy measures, one on bank capital supervision stringency and one on restrictions on LTVs. We find some evidence that the impact of low monetary policy rates on the softening of lending standards (softening of lending conditions due to bank capital, liquidity costs, or competition pressures) is reduced by more stringent policy on either bank capital or LTV. Note that this is generally not the case with overall lending conditions (columns 1 and 4), but interestingly it holds with changes in lending standards due to bank balance sheet factors - notably, changes in lending conditions due to the bank liquidity position for the capital supervision measure and changes in lending conditions due to bank competition for the LTV measure. This further reinforces the interpretation that more stringent prudential policy reduces the impact of low monetary policy rates on the supply of loans and on bank risk-taking.

\subsection{Lending Conditions and Standards During the Crisis}

The results are reported as follows. We first analyze the impact of short-term interest rates on overall lending conditions during the crisis (table 6) with no controls and using GLS estimation as in

\footnotetext{
${ }^{23}$ Coefficients for both business and mortgage loans remain significant if we do not include time fixed effects. Results are also robust to not including lagged credit standards as a control variable or to introducing (or not) country fixed effects (results available upon request).
} 


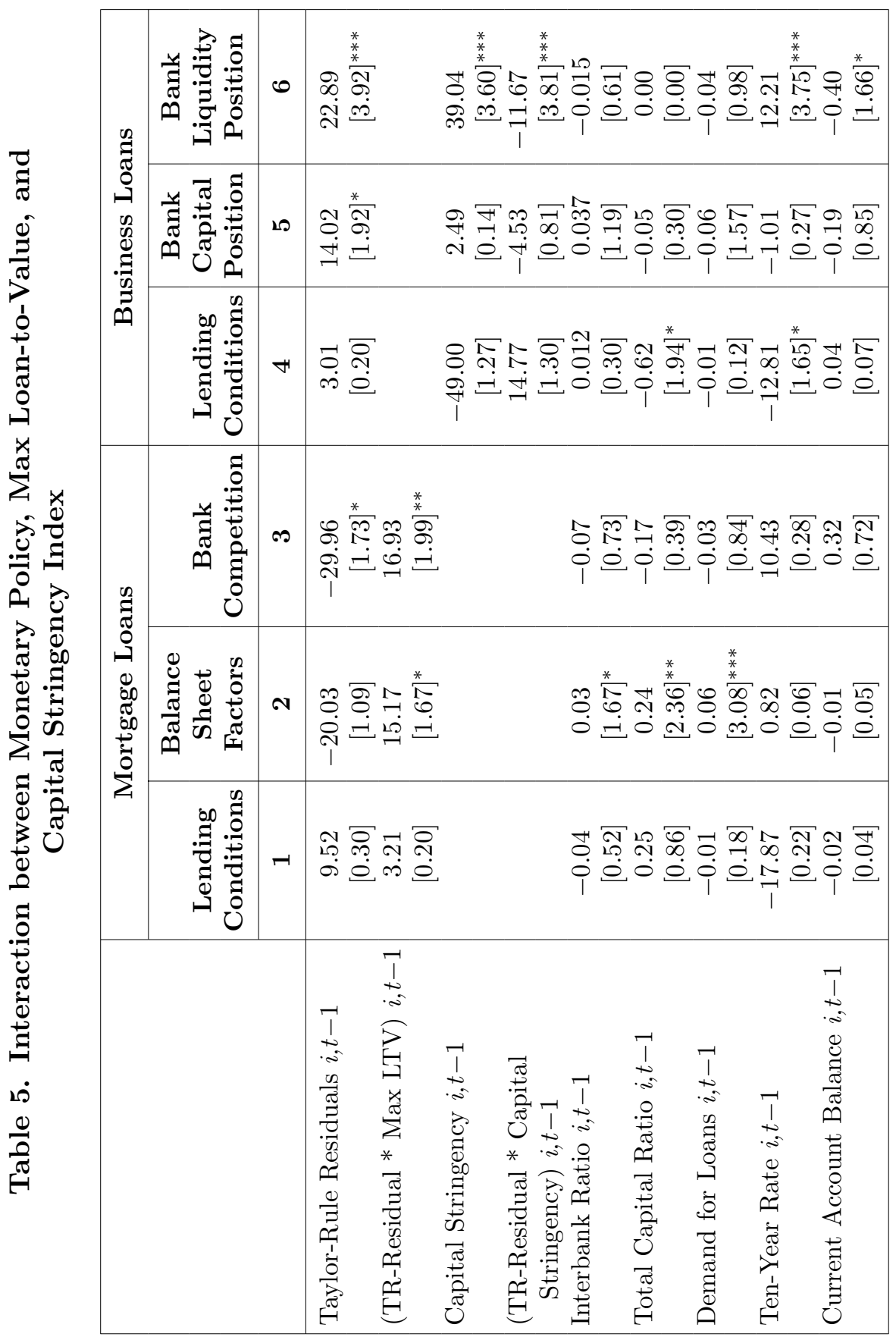




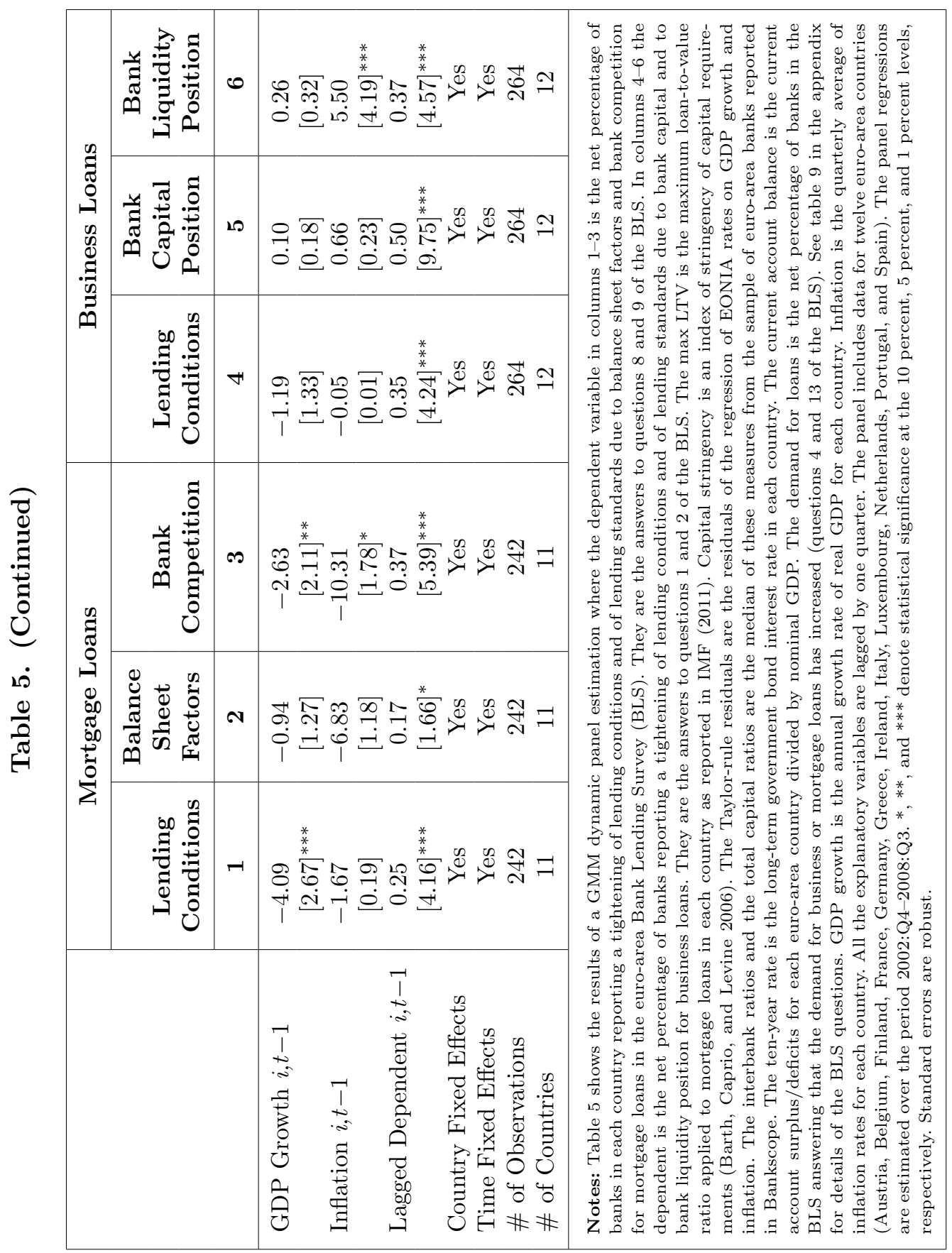




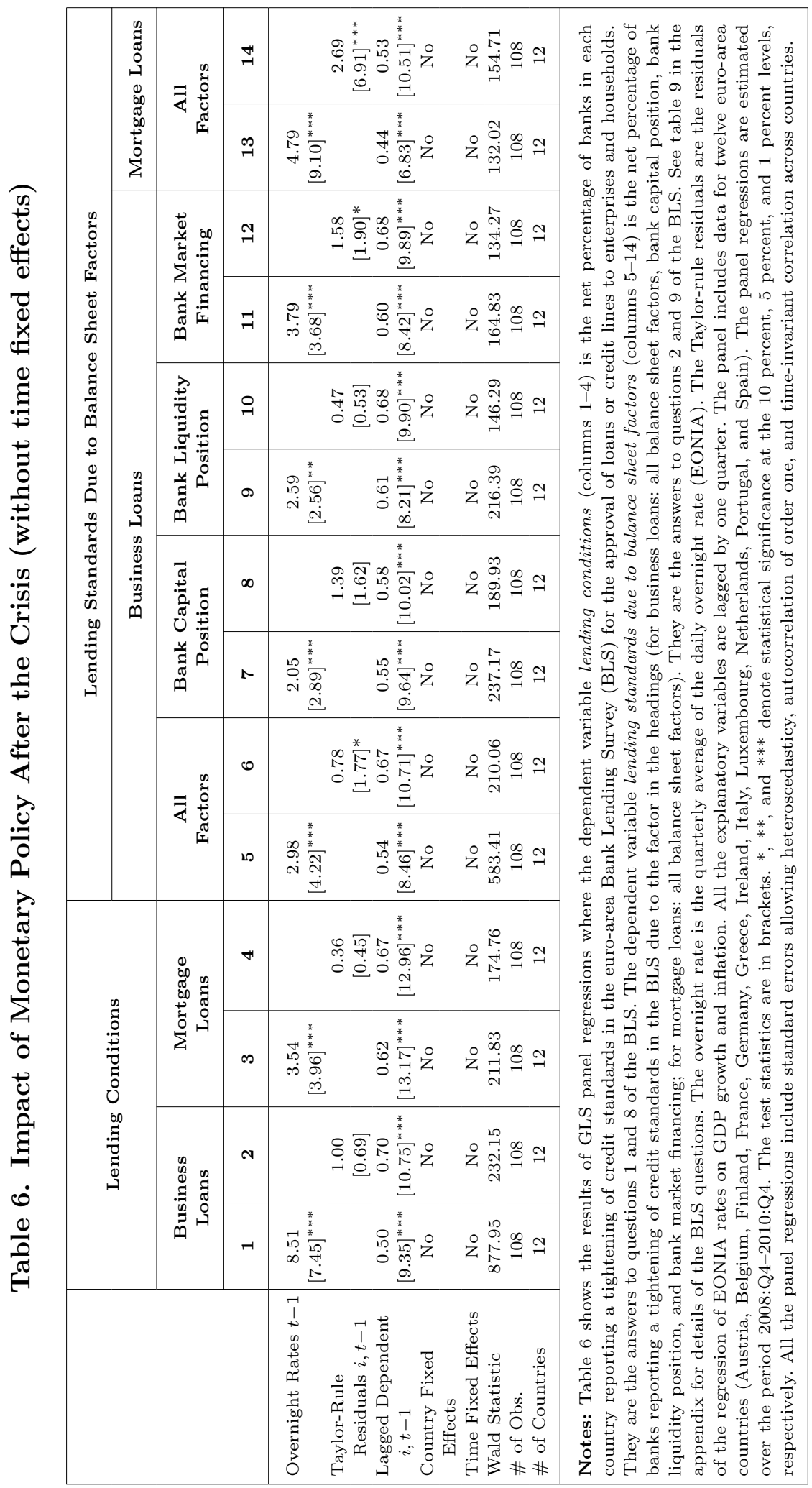


table 2. Then, we use GMM and include all the controls as we have done before the crisis, reporting results with and without time fixed effects (table 7). In the last set of estimations (table 8), we differentiate banks by the long-term liquidity borrowed from the Eurosystem, as explained in section 3 .

Table 7A shows that after the start of the crisis in 2008:Q3, low (monetary policy) short-term interest rates have softened overall lending conditions (columns 1 and 2) and tightened lending standards for firms due to bank capital and liquidity constraints (columns 5 to 12). Low monetary policy rates-by improving bank liquidity and capital - increase credit availability. The coefficients are always significant for business loans. ${ }^{24}$ In table 7B, we carry out similar estimations with GMM and include all the control variables, which may be more important than in the period before the crisis, given the large shocks that occurred during the crisis. The results of table 6 are confirmed, but only for business loans. The coefficient related to overall lending conditions for mortgage loans and to lending standards for mortgages due to balance sheet factors are not significant. In table $8 \mathrm{~A}$, when we do not include time fixed effects (due to the small number of observations), the coefficients of Taylor-rule residuals are significant also for lending conditions due to balance sheet factors (for business loans).

It is also interesting to note that the coefficient of total capital ratio is negative and mostly significant. This suggests that the banks entering the crisis with a better capital position soften lending conditions more.

To countervail the impact of the crisis and, in particular, to restore the transmission of the monetary policy in the euro area, the ECB has implemented a policy of full-allotment liquidity provision to the banking sector. Moreover, the central bank has stepped up the scale of provision of long-term liquidity (longer than threemonth maturity). In the last part of the analysis, we also take into account the long-term liquidity provisions of the ECB.

\footnotetext{
${ }^{24}$ It should be noted that the number of observations after the crisis is significantly lower than in the previous regressions. This may decrease significantly the power of the estimation.
} 


\begin{tabular}{|c|c|c|c|c|}
\hline \multirow{10}{*}{ 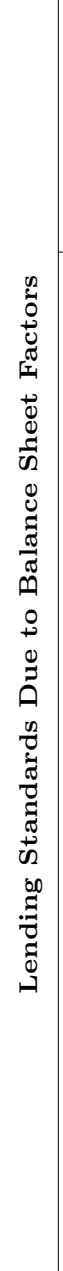 } & \multirow{2}{*}{ 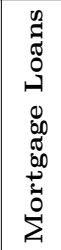 } & \multirow{2}{*}{ 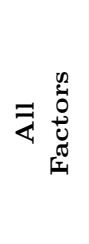 } & $\underset{-}{H}$ & 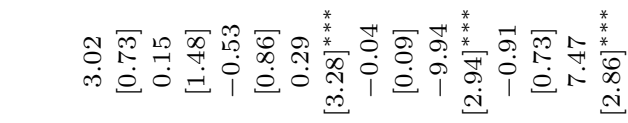 \\
\hline & & & $\stackrel{m}{\sim}$ & 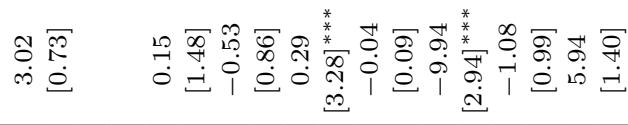 \\
\hline & & 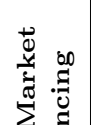 & $\stackrel{\sim}{\sim}$ & 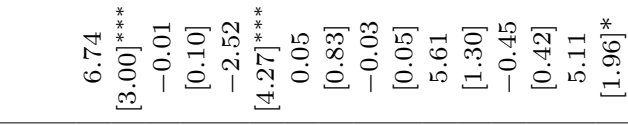 \\
\hline & & పี & $\vec{F}$ & 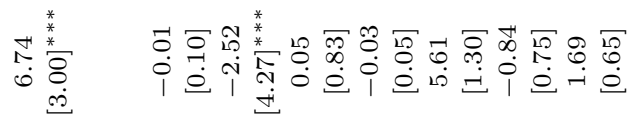 \\
\hline & & 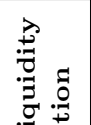 & $\stackrel{ }{-}$ & 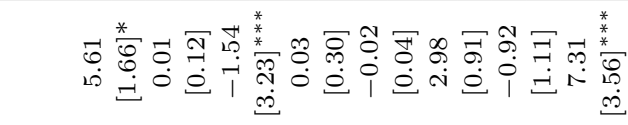 \\
\hline & 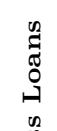 & 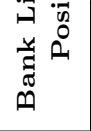 & 0 & 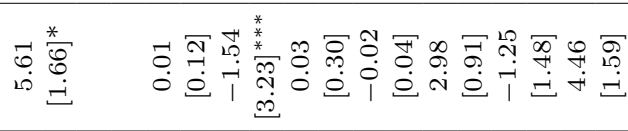 \\
\hline & 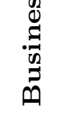 & 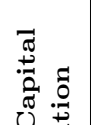 & $\infty$ & 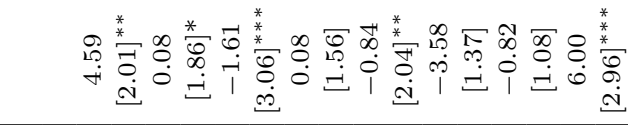 \\
\hline & & 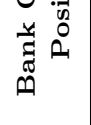 & $\wedge$ & 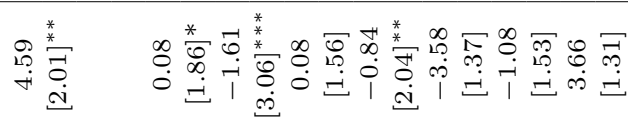 \\
\hline & & $=\stackrel{n}{0} 0$ & 0 & 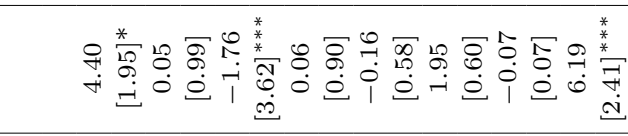 \\
\hline & & 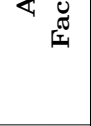 & 10 & 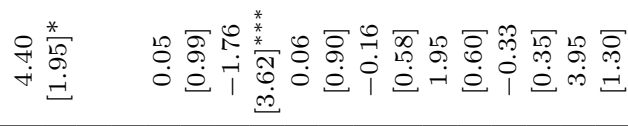 \\
\hline & & 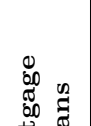 & 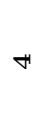 & 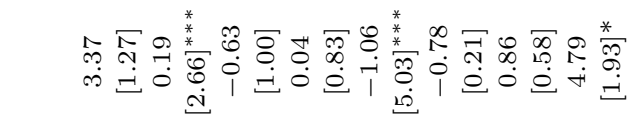 \\
\hline 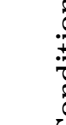 & 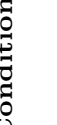 & 茓 & $\infty$ & 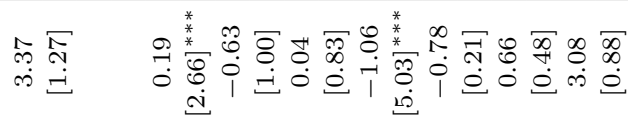 \\
\hline 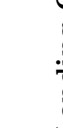 & $\underbrace{}_{\substack{0 \\
0}}$ & 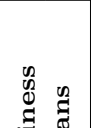 & N & 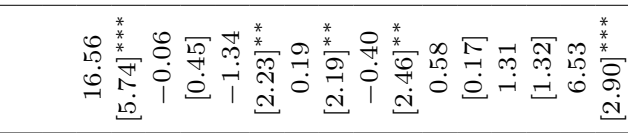 \\
\hline & & $\stackrel{0}{5} \stackrel{0}{9}$ & $r$ & 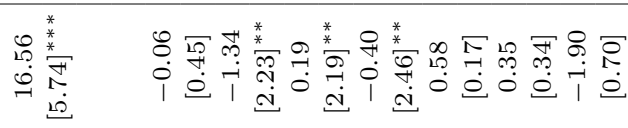 \\
\hline & & & & 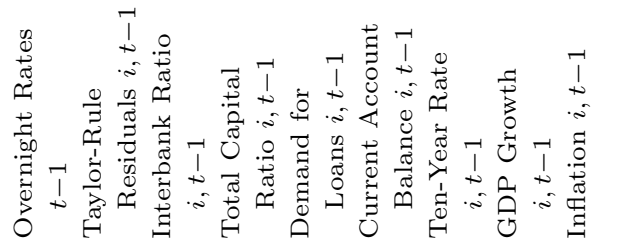 \\
\hline
\end{tabular}




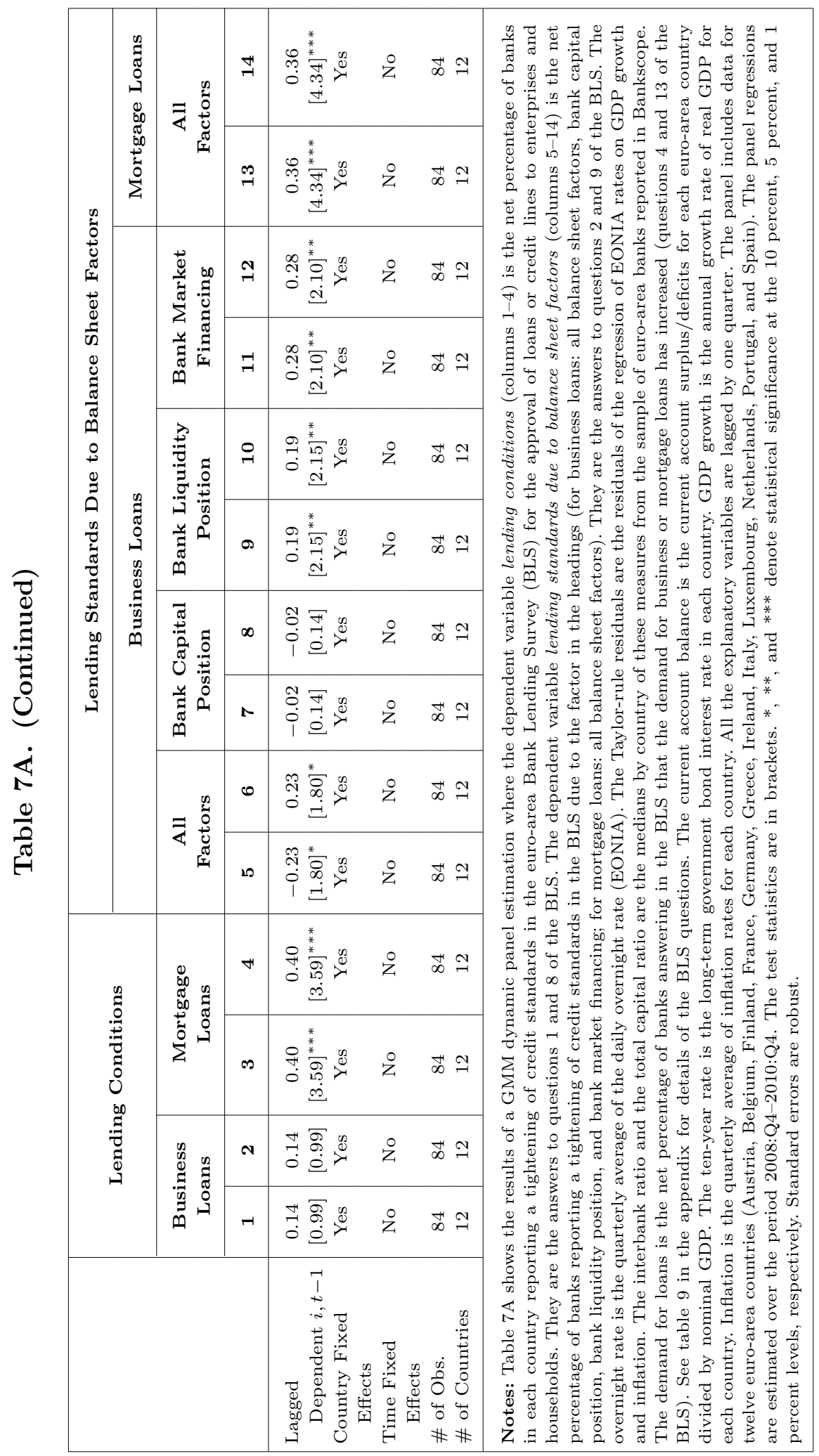




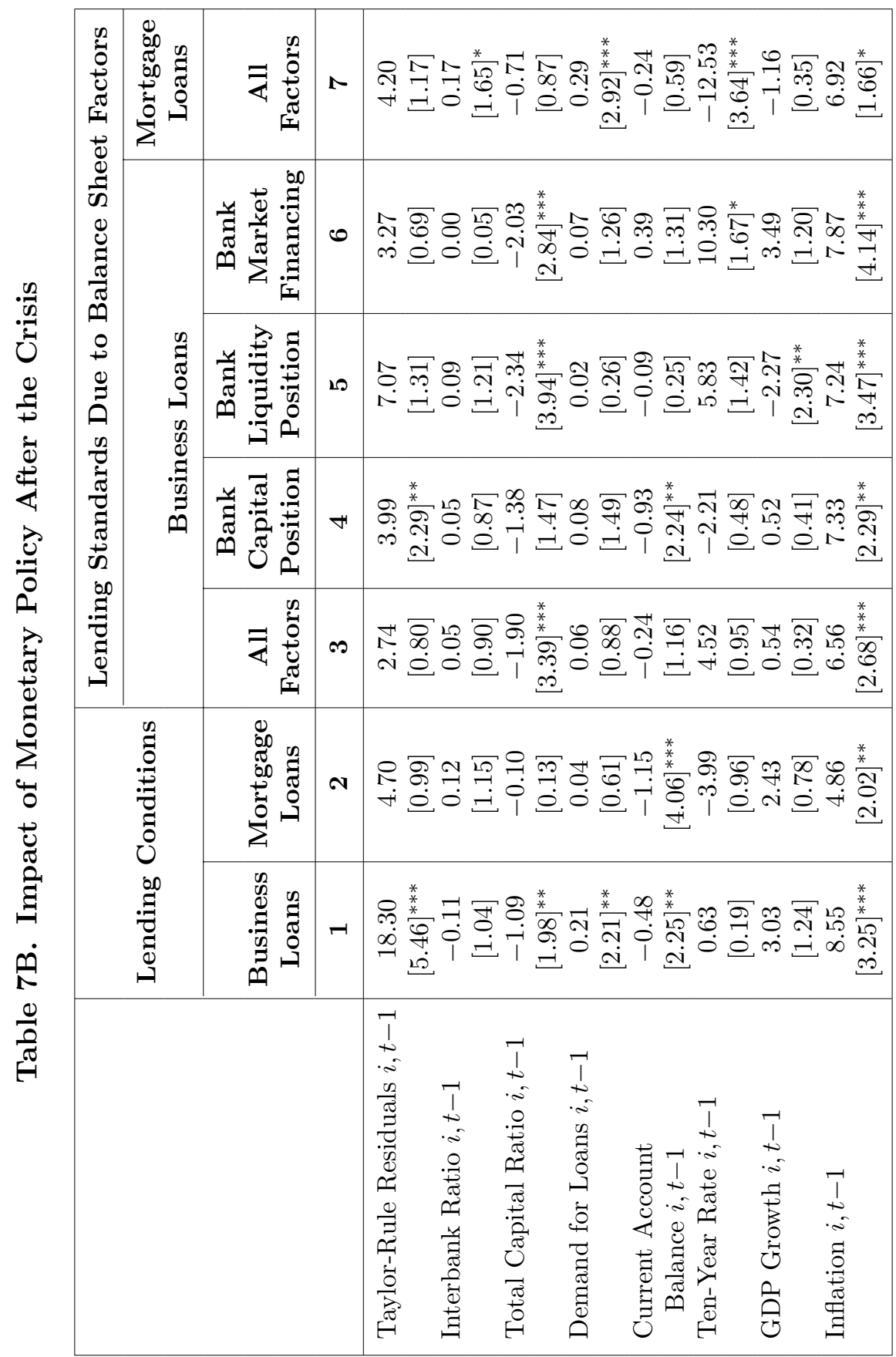




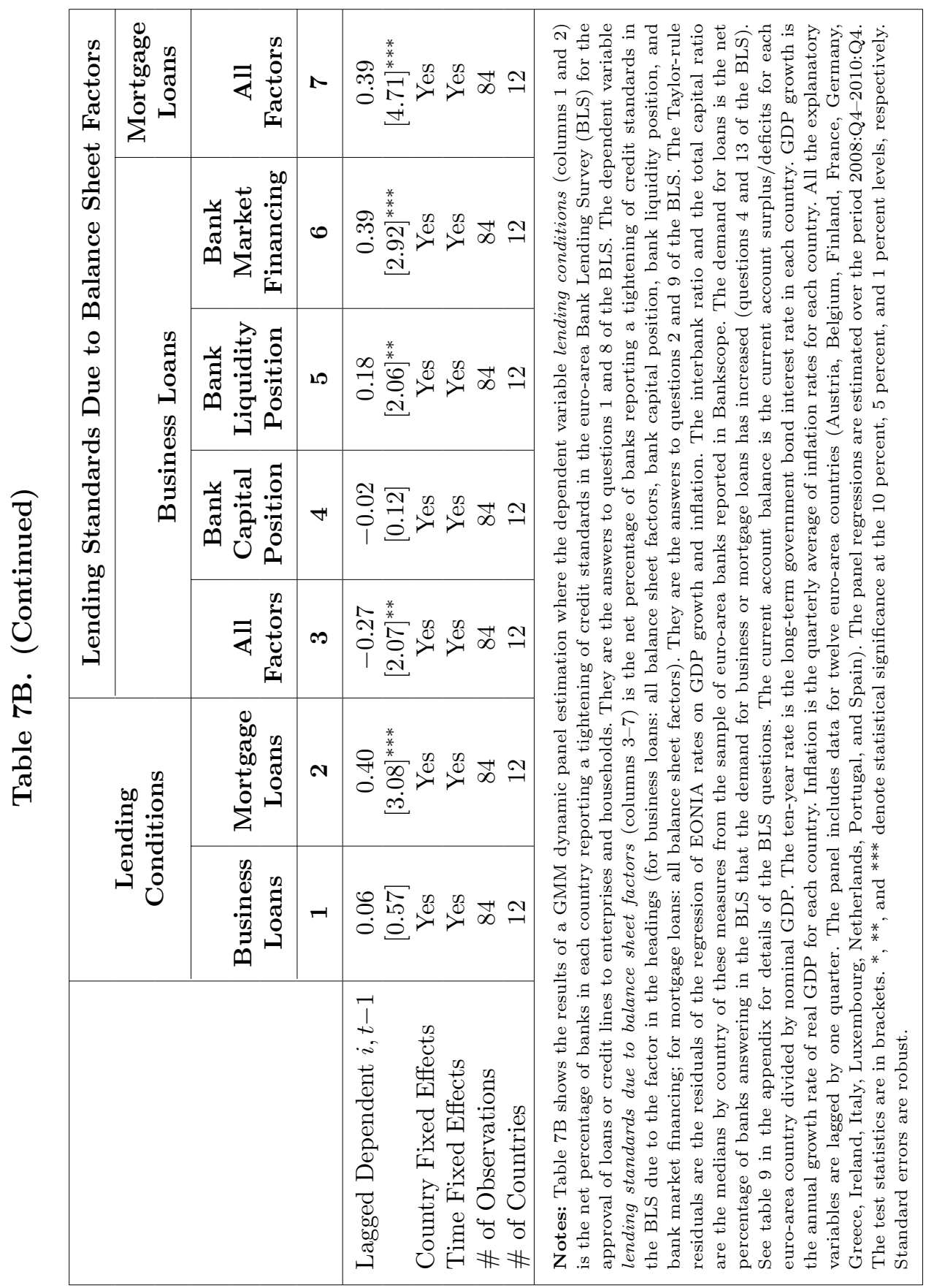


In tables $8 \mathrm{~A}$ and $8 \mathrm{~B}$ (with and without time fixed effects) we introduce the long-term liquidity provided by the ECB at the country level (scaled by GDP) and also the interaction between the measure of monetary rates (Taylor-rule residuals) and the central bank liquidity. The results of the estimation suggest that the impact of short-term rates is stronger for banks that borrow more the longterm liquidity provided by the ECB (those banks with hampered access to the private, wholesale markets).

All in all, our results are consistent with a mechanism in which the banking sector is facing significant liquidity constraints; lower monetary policy rates combined with access to Eurosystem longterm liquidity reduce these liquidity constraints (see the coefficient of the interaction between short-term rates and liquidity provisions), in turn softening lending standards applied by the banks. Therefore, monetary policy actions contribute to increasing credit availability for firms and households. In other words, the provision of longterm liquidity helped to restore the transmission of monetary policy through the bank lending channel.

\section{Conclusions}

Commentators and academics have, since the beginning of the 2008 crisis, argued that keeping monetary policy rates too low can increase banks' appetite for credit and liquidity risk due to banks' moral hazard problems. This, in turn, may increase the likelihood of a financial crisis originating from the accumulation of bank risk in the system. But once the risk in the balance sheets of banks realizes and the crisis starts, the banking sector may then need low monetary policy rates to support credit supply for firms and households - especially the banks with weaker balance sheet capacity.

In this paper we analyze some of these issues in the euro area. We believe that our findings shed light on the impact of monetary policy on lending conditions and standards, with implications concerning the origins and development of the current crisis, but also have important forward-looking policy implications. In particular, results suggest that monetary policy rates affect bank stability, and their impact depends both on bank balance sheet strength and on banking prudential policy. Therefore, monetary policy and prudential policy are connected and influence each other. Monetary policy decisions 


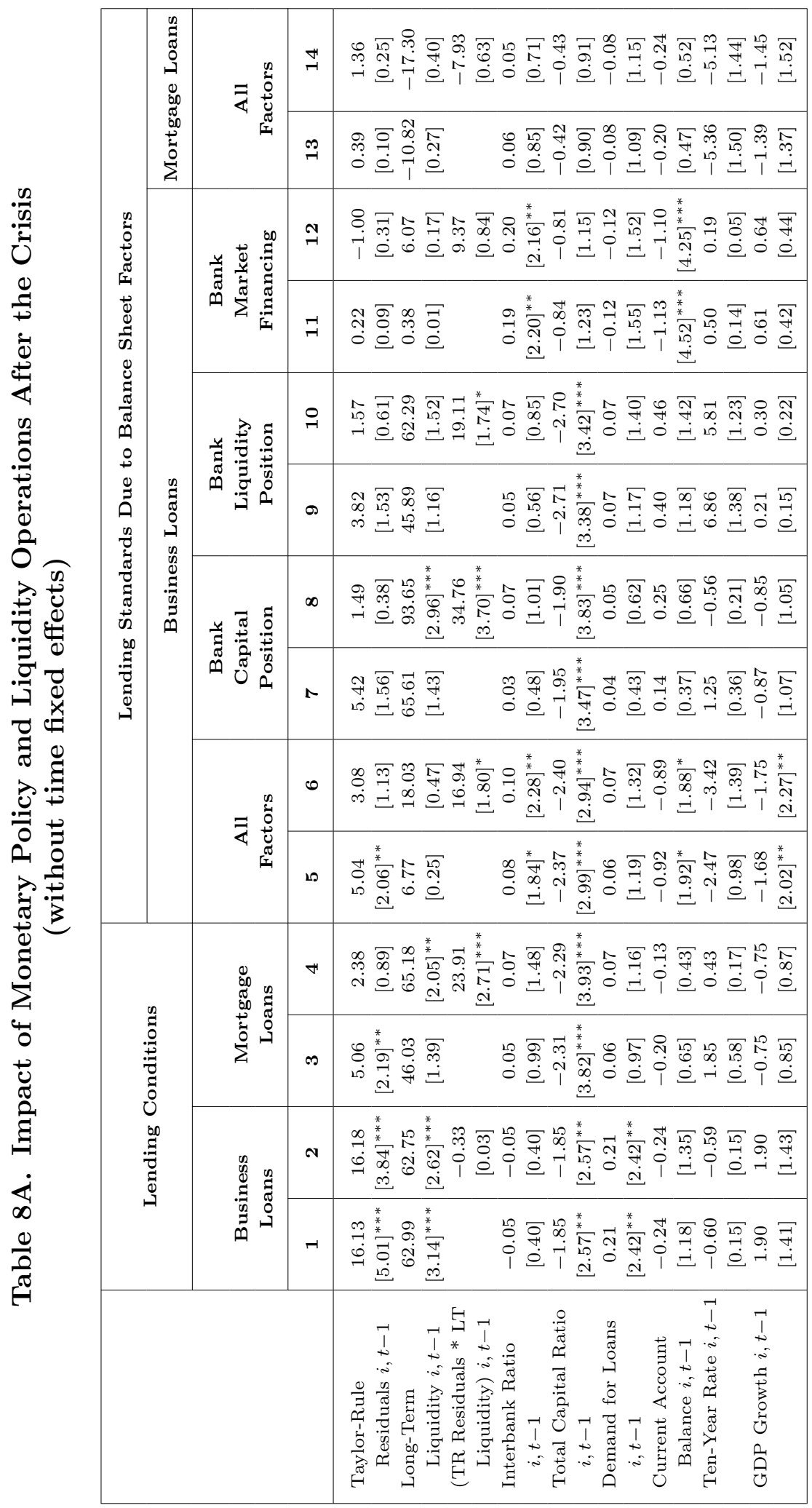




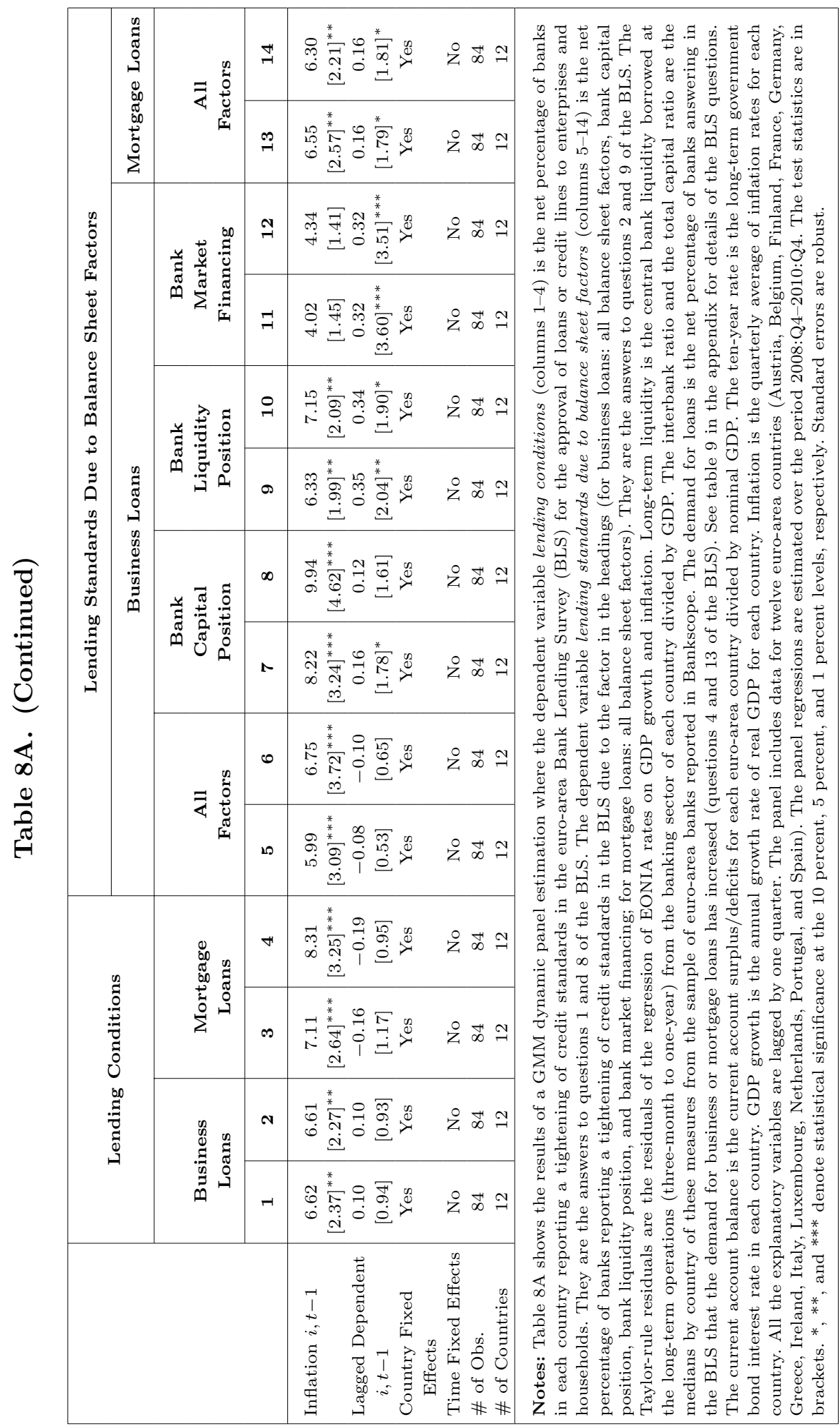




\begin{tabular}{|c|c|c|c|c|}
\hline \multirow{10}{*}{ 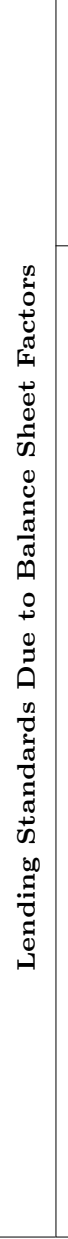 } & \multirow{2}{*}{ 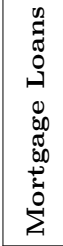 } & \multirow{2}{*}{ 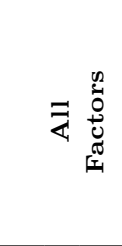 } & $\underset{-H}{H}$ & 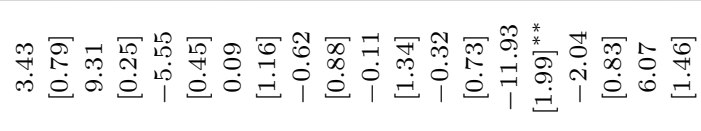 \\
\hline & & & $\stackrel{m}{\rightarrow}$ & 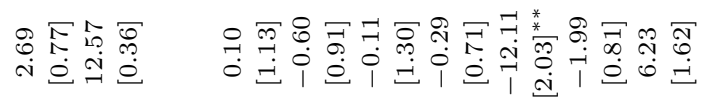 \\
\hline & & 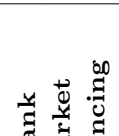 & $\stackrel{\sim}{\sim}$ & 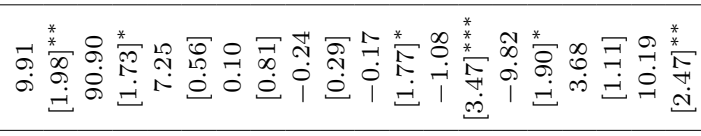 \\
\hline & & $\oplus \sum^{\infty} \sum_{i=1}^{\sigma}$ & $\exists$ & 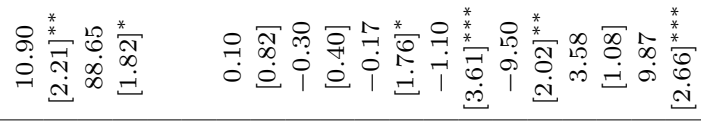 \\
\hline & & 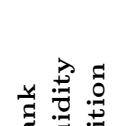 & $\stackrel{\circ}{\sim}$ & 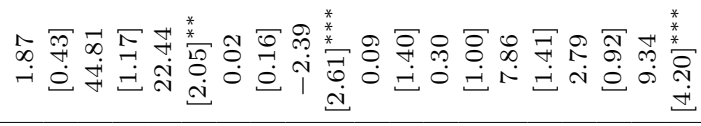 \\
\hline & 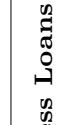 & 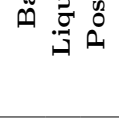 & 0 & 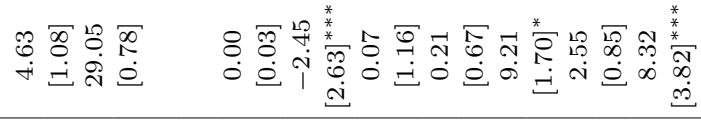 \\
\hline & $\underset{\substack{\leftrightarrows \\
0}}{\stackrel{0}{0}}$ & 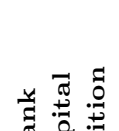 & $\infty$ & 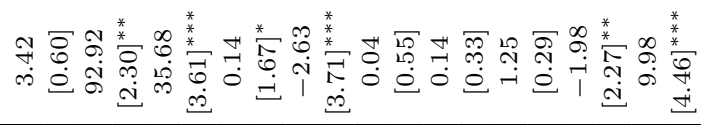 \\
\hline & & ต & $\wedge$ & 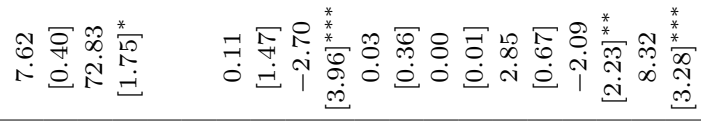 \\
\hline & & $\exists \stackrel{0}{0}$ & 0 & 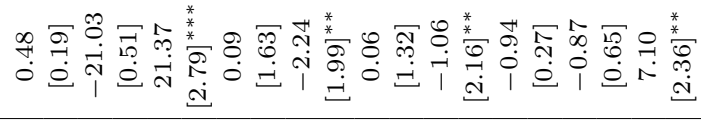 \\
\hline & & 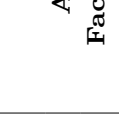 & 10 & 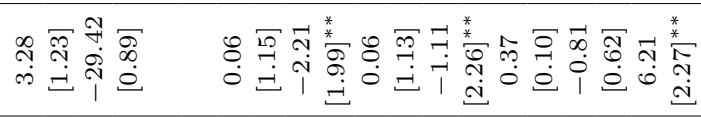 \\
\hline & & $\begin{array}{l}0 \\
\infty_{\infty}^{\infty} \\
\underbrace{\infty}_{0} \\
+\infty\end{array}$ & $H$ & 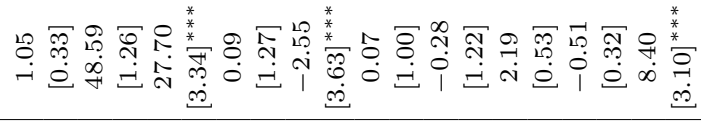 \\
\hline & 焉 & 䓹 & $\infty$ & 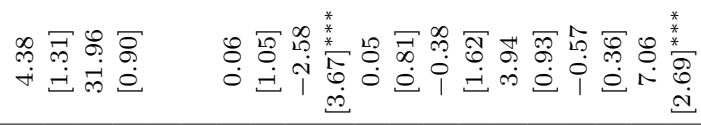 \\
\hline & 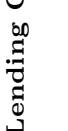 & 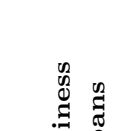 & $\boldsymbol{N}$ & 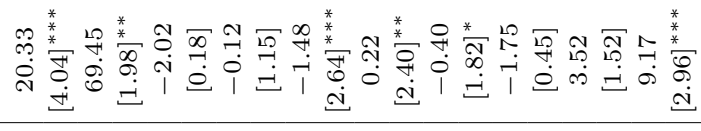 \\
\hline & 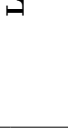 & 药 & $r$ & 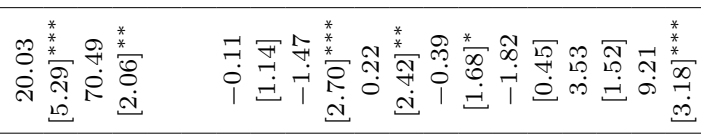 \\
\hline & & & & 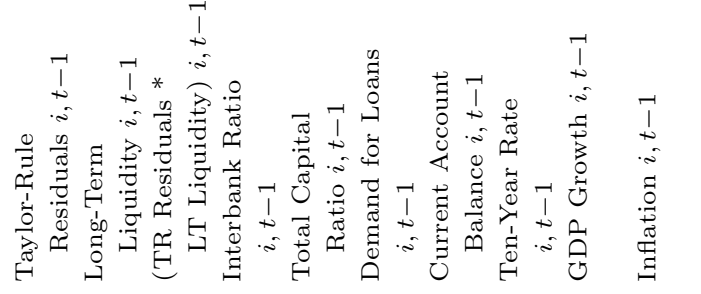 \\
\hline
\end{tabular}




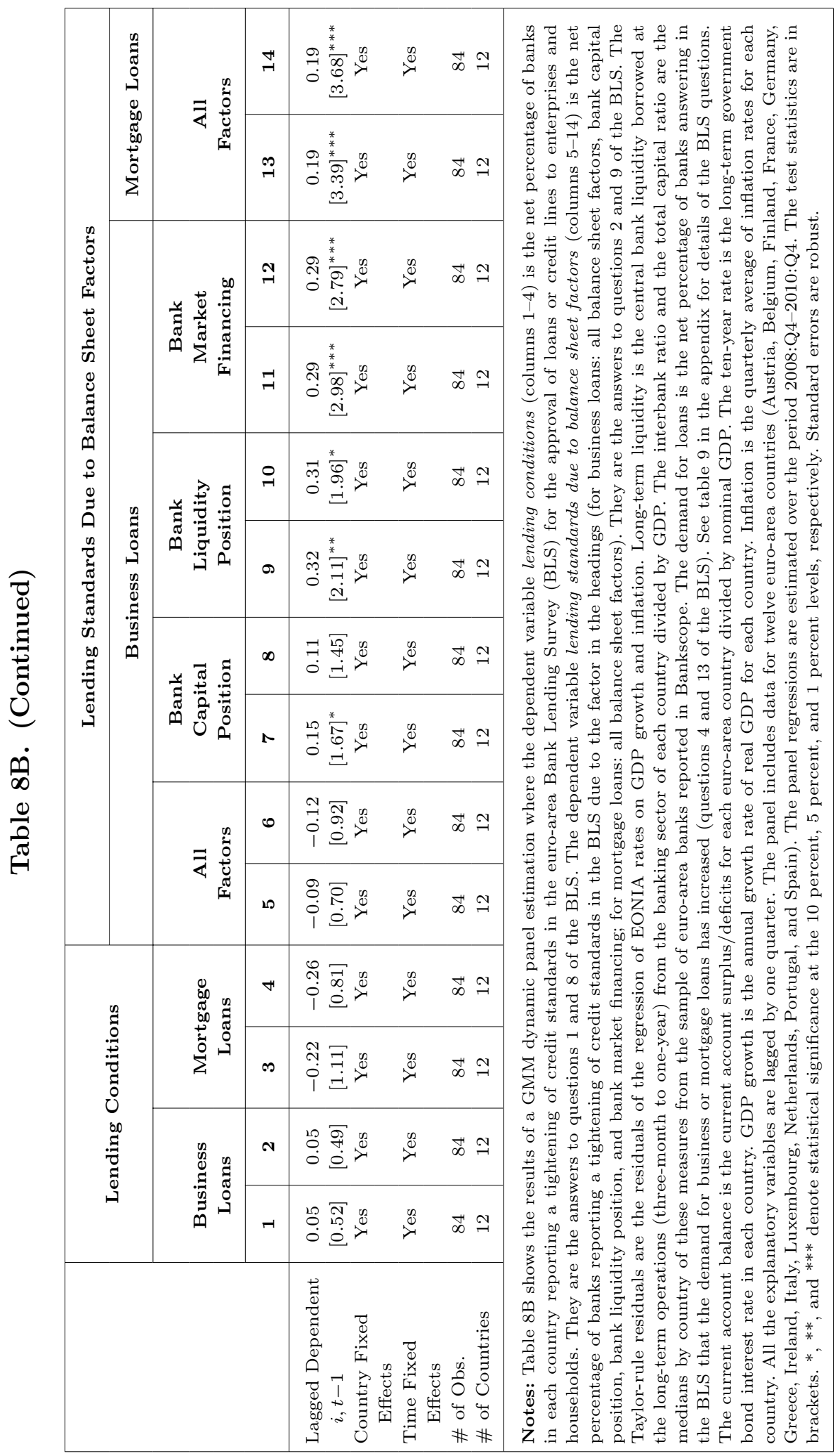


should pay more attention to financial stability issues, while banking prudential supervision and regulation should take into account the effects induced by a low monetary policy rate environment.

In crisis times, we also show that monetary policy rates have an effect on lending conditions and that non-standard monetary policy measures, primarily the provision of liquidity at longer maturity, can enhance this effect.

The results may also support the need for monetary policy to lean against the wind in good times, though macroprudential policies (for example, time-varying and countercyclical LTV values or capital requirements) may alleviate this need. Moreover, if the balance sheet position of banks were stronger when entering a crisis period (for example, with higher bank capital), there would be less need for low monetary policy rates to support credit supply from banks, which otherwise could potentially foster excessive bank risktaking in the medium term. Our results, therefore, support the new responsibilities of central banks on macroprudential supervision and regulation, in particular the new responsibilities of the European Central Bank and of the Federal Reserve on macroprudential policies to monitor systemic risk. 


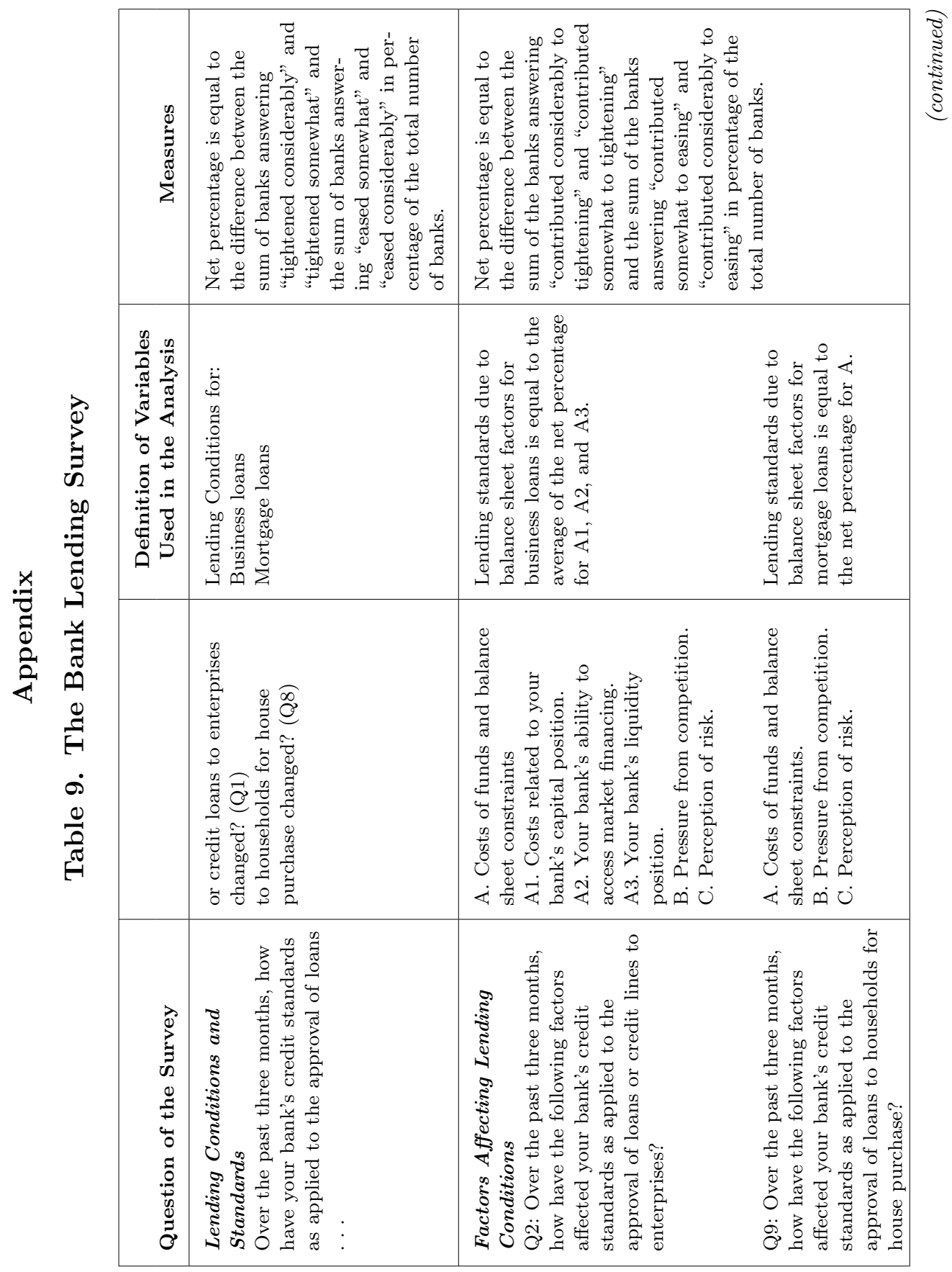




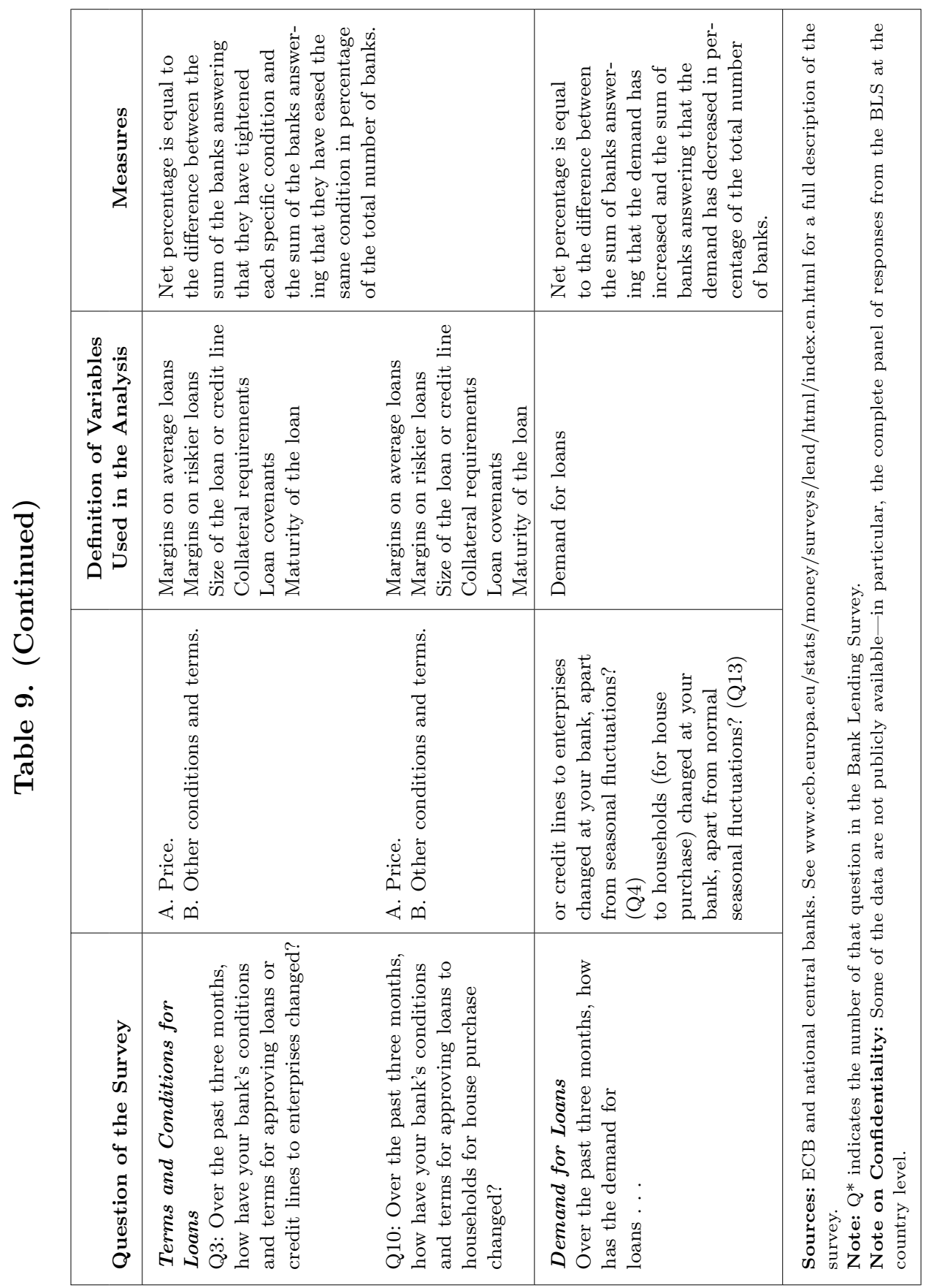




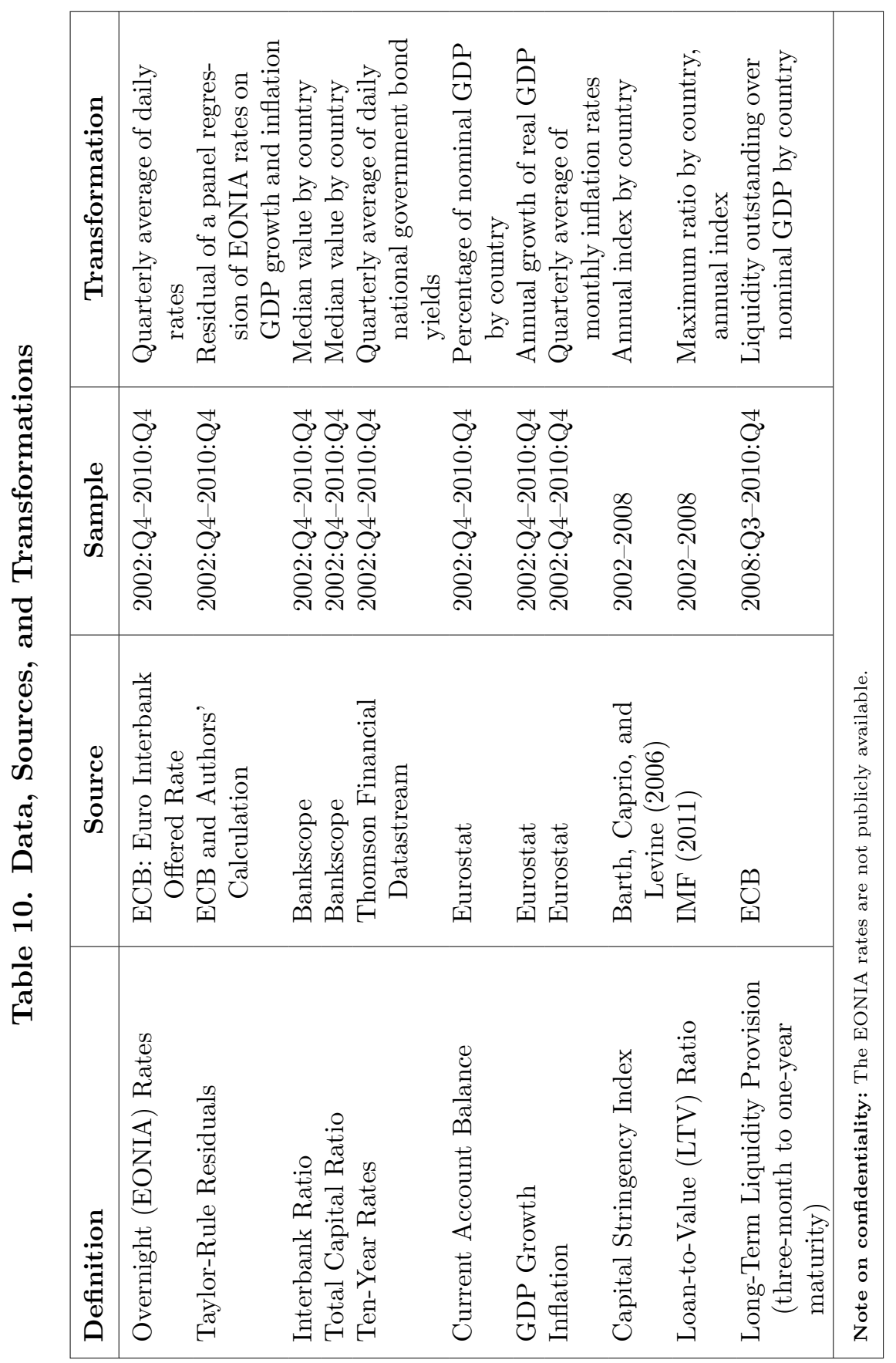




\section{References}

Acharya, V., and M. Richardson. 2009. "Causes of the Financial Crisis." Critical Review 21 (2-3): 195-210.

Adrian, T., and H. S. Shin. 2010a. "Financial Intermediaries and Monetary Economics." In Handbook of Monetary Economics, ed. B. M. Friedman and M. Woodford, 604-50. New York, NY: Elsevier.

-. 2010b. "Liquidity and Leverage." Journal of Financial Intermediation 19 (3): 418-37.

Allen, F., and E. Carletti. 2010. "An Overview of the Crisis: Causes, Consequences and Solutions." International Review of Finance 10 (1): 1-26.

Allen, F., M. Chui, and A. Maddaloni. 2004. "Financial Systems in Europe, the USA and Asia." Oxford Review of Economic Policy 20 (4): 490-508.

Allen, F., and D. Gale. 2000. "Bubbles and Crises." Economic Journal 110 (460): 236-55.

- 2004. "Asset Price Bubbles and Monetary Policy." In Global Governance and Financial Crises, ed. M. Desai and Y. Said. Routledge.

- 2007. Understanding Financial Crises. Oxford University Press.

Allen, F., and K. Rogoff. 2011. "Asset Prices, Financial Stability and Monetary Policy." Paper presented at the Swedish Riksbank Workshop on Housing Markets, Monetary Policy and Financial Stability.

Arellano, M. 2003. Panel Data Econometrics. Oxford University Press: Advanced Texts in Econometrics.

Arellano, M., and S. Bond. 1991. "Some Tests of Specification for Panel Data: Monte Carlo Evidence and an Application to Employment Equations." Review of Economic Studies 58 (2): 277-97.

Barth, R. J., G. Caprio, and R. Levine. 2006. Rethinking Bank Regulation. Cambridge University Press.

Berg, J., A. van Rixtel, A. Ferrando, G. de Bondt, and S. Scopel. 2005. "The Bank Lending Survey for the Euro Area." ECB Occasional Paper No. 23. 
Bernanke, B. S. 2007. "The Financial Accelerator and the Credit Channel." Speech at The Credit Channel of Monetary Policy in the Twenty-first Century Conference, Federal Reserve Bank of Atlanta, Atlanta, Georgia, June 15.

- 2010. "Monetary Policy and the Housing Bubble." Speech at the Annual Meeting of the American Economic Association, Atlanta, Georgia, January 3.

Bernanke, B. S., and A. S. Blinder. 1992. "The Federal Funds Rate and the Channels of Monetary Transmission." American Economic Review 82 (4): 901-21.

Bernanke, B. S., and M. Gertler. 1995. "Inside the Black Box: The Credit Channel of Monetary Policy Transmission." Journal of Economic Perspectives 9 (4): 27-48.

Besley, T., and P. Hennessy. 2009. "Letter to Her Majesty The Queen." British Academy, July 22.

Blanchard, O. 2008. "The State of Macro." NBER Working Paper No. 14259.

. 2009. "The Crisis: Basic Mechanisms, and Appropriate Policies." MIT Department of Economics, Working Paper No. 09-01.

Borio, C., and P. Lowe. 2002. "Asset Prices, Financial and Monetary Stability: Exploring the Nexus." BIS Working Paper No. 114.

Borio, C., and H. Zhu. 2008. "Capital Regulation, Risk-Taking and Monetary Policy: A Missing Link in the Transmission Mechanism?" BIS Working Paper No. 268.

Calomiris, C. W. 2008. "The Subprime Turmoil: What's Old, What's New, and What's Next." Paper presented at the 9th Jacques Polak Annual Research Conference, hosted by the International Monetary Fund, Washington, DC, November 13-14.

Camacho, M., G. Pérez-Quiros, and L. Saiz. 2008. "Do European Business Cycles Look Like One?" Journal of Economic Dynamics and Control 32 (7): 2165-90.

Christiano, L. J., M. Eichenbaum, and C. Evans. 1996. "The Effects of Monetary Policy Shocks: Evidence from the Flow of Funds." Review of Economics and Statistics 78 (1): 16-34.

Ciccarelli, M., A. Maddaloni, and J.-L. Peydró. 2010. "Trusting the Bankers: A New Look at the Credit Channel of Monetary Policy." ECB Working Paper No. 1228.

Dell'Ariccia, G., L. Laeven, and R. Marquez. 2011. "Monetary Policy, Leverage, and Bank Risk-Taking." Mimeo, International Monetary Fund. 
Dell'Ariccia, G., and R. Marquez. 2006. "Lending Booms and Lending Standards." Journal of Finance 61 (5): 2511-46.

Diamond, D. W., and R. G. Rajan. 2006. "Money in a Theory of Banking." American Economic Review 96 (1): 30-53.

- 2009. "The Credit Crisis: Conjectures about Causes and Remedies." Mimeo.

- 2012. "Illiquid Banks, Financial Stability, and Interest Rate Policy." Journal of Political Economy 120 (3): 552-91.

Gertler, M., and N. Kiyotaki. 2010. "Financial Intermediation and Credit Policy in Business Cycle Analysis." In Handbook of Monetary Economics, ed. B. M. Friedman and M. Woodford. New York, NY: Elsevier.

Giavazzi, F., and A. Giovannini. 2010. "The Low Interest Rate Trap." VoxEU, July.

Holmström, B., and J. Tirole. 2011. Inside and Outside Liquidity. Cambridge, MA: MIT Press.

International Monetary Fund. 2011. "Housing Finance and Financial Stability_Back to Basics?" Global Financial Stability Report (April): Chapter 3.

Jiménez G., S. Ongena, J.-L. Peydró, and J. Saurina. 2012a. "Credit Supply and Monetary Policy: Identifying the Bank Balance-Sheet Channel with Loan Applications." American Economic Review 102 (5): 2301-26.

- 2012b. "Hazardous Times for Monetary Policy: What Do Twenty-Three Million Bank Loans Say About the Effects of Monetary Policy on Credit Risk?" UPF Working Paper.

Kane, E. 1989. The SELL Insurance Mess: How Did It Happen? Cambridge, MA: MIT Press.

Kashyap, A. K., and J. C. Stein. 2000. "What Do a Million Observations on Banks Say About the Transmission of Monetary Policy?" American Economic Review 90 (3): 407-28.

Laeven, L., and R. Levine. 2009. "Bank Governance, Regulation, and Risk-Taking." Journal of Financial Economics 93 (2): 259-75.

Lown, C., and D. P. Morgan. 2006. "The Credit Cycle and the Business Cycle: New Findings Using the Loan Officer Opinion Survey." Journal of Money, Credit and Banking 38 (6): 1575-97. Maddaloni, A., and J.-L. Peydró. 2011. "Bank Risk-Taking, Securitization, Supervision and Low Interest Rates: Evidence from US 
and Euro Area Lending Standards." Review of Financial Studies 24 (6): 2121-65.

Rajan, R. G. 2005. "Has Financial Development Made the World Riskier?" NBER Working Paper No. 11728.

- 2010a. Correcting Krugman. New York Times.

- 2010b. Fault Lines. Princeton, NJ: Princeton University Press.

Reinhart, C., and K. Rogoff. 2009. This Time Is Different: Eight Centuries of Financial Folly. Princeton, NJ: Princeton University Press.

Ruckes, M. 2004. "Bank Competition and Credit Standards." Review of Financial Studies 17 (4): 1073-1102.

Stiglitz, J., and A. Weiss. 1981. "Credit Rationing in Markets with Imperfect Information." American Economic Review 71 (3): 393410.

Taylor, J. B. 2007. "Housing and Monetary Policy." NBER Working Paper No. 13682.

- 2008. "The Financial Crisis and the Policy Responses: An Empirical Analysis of What Went Wrong." In A Festschrift in Honour of David Dodge's Contributions to Canadian Public Policy, 1-18. Bank of Canada. Reprinted in Critical Review, 2009, $21(2-3): 341-64$.

Trichet, J. C. 2009. "The ECB's Enhanced Credit Support." Keynote address at the University of Munich, July 13.

Valencia, F. 2011. "Monetary Policy, Bank Leverage, and Financial Stability." IMF Working Paper No. 11/244 (October). 